Article

\title{
Assessment of the Main Geochemical Processes Affecting Surface Water and Groundwater in a Low-Lying Coastal Area: Implications for Water Management
}

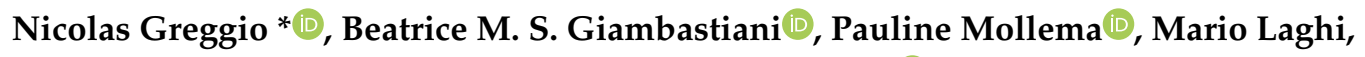 \\ Donato Capo, Giovanni Gabbianelli, Marco Antonellini 1 and Enrico Dinelli \\ Department of Biological, Geological and Environmental Sciences, Alma Mater Studiorum-University of \\ Bologna, Piazza di Porta San Donato 1, 40126 Bologna, Italy; beatrice.giambastiani@unibo.it (B.M.S.G.); \\ pmollema@gmail.com (P.M.); mariolaghi@gmail.com (M.L.); bangu@libero.it (D.C.); \\ giovanni.gabbianelli@unibo.it (G.G.); m.antonellini@unibo.it (M.A.); enrico.dinelli@unibo.it (E.D.) \\ * Correspondence: nicolas.greggio2@unibo.it
}

Received: 22 May 2020; Accepted: 11 June 2020; Published: 16 June 2020

\begin{abstract}
Hydrogeochemical analyses were carried out to identify geochemical processes occurring in the low-lying coastal aquifer of Ravenna, North Adriatic Sea (Italy). The area is characterized by a complex coexistence of several environments: coastal dunes, paleodunes, pine forests, freshwater wetlands, rivers, brackish lagoons, gravel pit lakes, reclaimed lands, agricultural fields and industrial areas. Water quality is of primary importance for the sustainability of these, areas and a full understanding of geochemical processing is fundamental for their management. A total of 104 water samples was collected from groundwater wells and surface water bodies, and analyzed for the major and trace elements (TEs). Field measurements of chemical-physical parameters were carried out by a multiparameter device XS PCD650; major elements were analyzed following the Italian National Environmental Agency standards (APAT-IRSA 2003), while TEs were analyzed by ICP-AES/ICP-MS. The major findings include: organic matter degradation in salinized and anoxic conditions; TEs concentrations related to water-sediment interactions, i.e., adsorption, ion exchange, redox reactions, mineral dissolution and precipitation; anthropogenic contamination from pesticides and fertilizers use; pollution from industrial district; TEs enrichments and depletion due to groundwater salinization and water management practices; comparison of TEs concentrations with respect to national and international thresholds. The findings can provide water managers and local authorities with a comprehensive framework of the coastal water hydrochemistry, allowing a better understanding of the effects of current management practices and the design of mitigation measures to reduce water resource deterioration in the studied coastal area.
\end{abstract}

Keywords: geochemistry; $\mathrm{Cl}^{-} / \mathrm{Br}^{-}$molar ratio; trace elements; coastal aquifer; water resource management; sulphate reduction; organic matter degradation; salinization

\section{Introduction}

Coastal areas are the most populated land on Earth. As reported by Kummu et al. [1], the population in the near-coast zone ( $<100 \mathrm{~km}$ from coast) has passed from 0.4 billion to 1.9 billion in the period 1900-2010, and it is projected to reach over 2.4 billion people by 2050. Thus, coastal water resources, both groundwater (GW) and surface water (SW), are strongly affected by anthropic activities and natural processes [2]. Water is consumed for human, agricultural or industry purposes, contaminated by wastewater, or managed through drainage/recharge, land reclamation and rivers diversion. On the 
other hand, surface topography, natural subsidence, saltwater intrusion, marine storms and water-rock (sediment) interaction processes under an unprecedented climate change scenario, are natural processes involved in coastal water dynamics and quality [2-6].

Being at the edge of the terrestrial and marine environments, coastal waters are the location of freshwater/saltwater mixing and of biogeochemical cycles involving elements with continental or marine provenance $[3,4,7,8]$.

Worldwide, many coastal aquifers are affected by increasing salinization processes [9], because of groundwater over-exploitation [10], drainage [11,12] and sea level rise [13,14]. Exposing GW to direct evaporation, even gravel pit lakes under a Mediterranean climate can promote aquifer salinization [15]. Intensive crop cultivation and coastal forests exacerbate GW salinization because of their high evapotranspiration rates that make the hydrological budget negative [16]. In some cases, to reduce GW salinization, excess irrigation or uncontrolled water storage for irrigation purpose [17-19], as well as other managed aquifer recharge techniques, are put in place [20].

Major processes occurring in coastal GW can be identified using hydro-chemical classification, which defines the water-type via considering $\mathrm{Cl}^{-}$content, alkalinity, major cations and anions, and Base Exchange Index BEX [21]. Geochemical processes can be also identified by major element ratios, such as $\mathrm{Cl}^{-} / \mathrm{Br}^{-}$molar [22,23] and $\mathrm{Cl}^{-} / \mathrm{SO}_{4}{ }^{-}$equivalent ratios [12], and by using Trace Elements (TEs) as tracers of salinization and freshening processes [24].

In addition to salinization, water-rock (sediment) interaction processes contribute to GW geochemical compositions in coastal aquifers. Cation exchange in clay minerals and organic matter [25,26], redox reactions [27,28], mineral precipitation and dissolution [29-31], and organic matter degradation $[12,32,33]$ are demonstrated to affect major cations and anions concentrations, as well as TEs.

In coastal aquifers affected by saltwater intrusion, GW ionic strength can be very high, and TEs contamination is an increasing concern [34,35]. TEs can originate from agricultural, industrial and extractive activities [15,36-38], from the weathering of the host formations, or by cation or anion exchange reactions promoted by the intrusion of saline waters [31,35,37,39-42]. Later, TEs can be transported, dissolved or complexed along the water hydraulic gradient or precipitate in sediments, resulting in the contamination of water, soils, plants, and eventually human drinking water [43-45]. Thus, TEs presence obliges us to accurately assess their environmental dynamic [46,47].

As stated in the last IPPC report, the worldwide low-lying areas, and their groundwater, are forecasted to be the factors most affected by sea level rise induced by climate change [10], and the Po river floodplain will be one of the most damaged [14,48]. The coastal aquifers in the south-eastern Po river floodplain are strongly salinized because of recent deposition [49,50], groundwater over-exploitation, land subsidence, strong drainage [6,51-53] and the erosion of coastal dunes [54]. As described by Mollema et al. [53], using isotopes, the SW and GW of many different environments, such as coastal dunes (1), paleodunes (2), agricultural fields (3), gravel pit lakes (4), sea (5), lagoon (6), drainage channels (7) and rivers (8), have different characteristics and origins.

For the purposes of water characterization and management, there is a need for an improved understanding of the geochemical processes. This paper aims to characterize the coastal water hydrochemistry in the coastal area of Ravenna (Italy), by identifying the geochemical processes affecting the major elements and TEs. Keeping the 104 water samples grouped in the eight abovementioned "sampling environments" [53], a detailed description of the occurring biogeochemical processes in the GW system is performed. A focus on processes involving organic matter (OM) and a commentary of the occurrence, distribution and relations of several TEs-comparing their concentrations with guidelines and recommended values and evaluating their roles as hydrogeochemical tracers-is also presented. Lastly, a summary of the occurring geochemical processes and related implications for water management is reported. The findings provide water managers and local authorities with a comprehensive framework of the coastal water hydrochemistry, allowing a better understanding of 
the effects of current management practices, in order to design future prevention and/or mitigation measures to reduce water resource deterioration in the studied coastal area.

\section{Study Area}

The study area is in the south-eastern part of the Po River floodplain (Figure 1). It is a 10-km-wide strip of land parallel to the coast, about $400 \mathrm{~km}^{2}$ from the Reno to the Savio River, with Ravenna city located in the middle. In this area, intensive agriculture, industry, port activities and intensive tourism coexist. Most of the territory has recently dried-up through land reclamation processes [52]. Historical reconstruction dates the deposition between 1500 and 300 years before the present, and the southern area is the youngest [55]. The relative recent deposition lead to -0.5 to $-3 \mathrm{~mm} /$ year of natural subsidence $[56,57]$. Moreover, at the end of last century, an increase in the subsidence rate was caused by anthropogenic activities, primarily related to groundwater extraction from shallow and deep aquifers, as well as gas production from Plio-Pleistocene reservoirs, causing a rate of up to 50-100 mm/year [58-60]. The original flat topography around the mean sea level, with elevation ranging from $-2 \mathrm{~m}$ above sea level (a.s.l.) to $+3 \mathrm{~m}$ a.s.l., and the subsidence contribution impose mechanical drainage systems that lower the phreatic level, permitting water discharge to the sea and keeping the land dry for human activities [52]. A dense network of drainage ditches collects rainwater and runoff, and directs them to pumping stations during wet periods, while supplying irrigation water during dry periods [60]. In addition to this, saltwater intrusion in the phreatic aquifer, seawater encroachment along the rivers, sea level rise and insufficient aquifer recharge all cause soil and groundwater salinization [61].

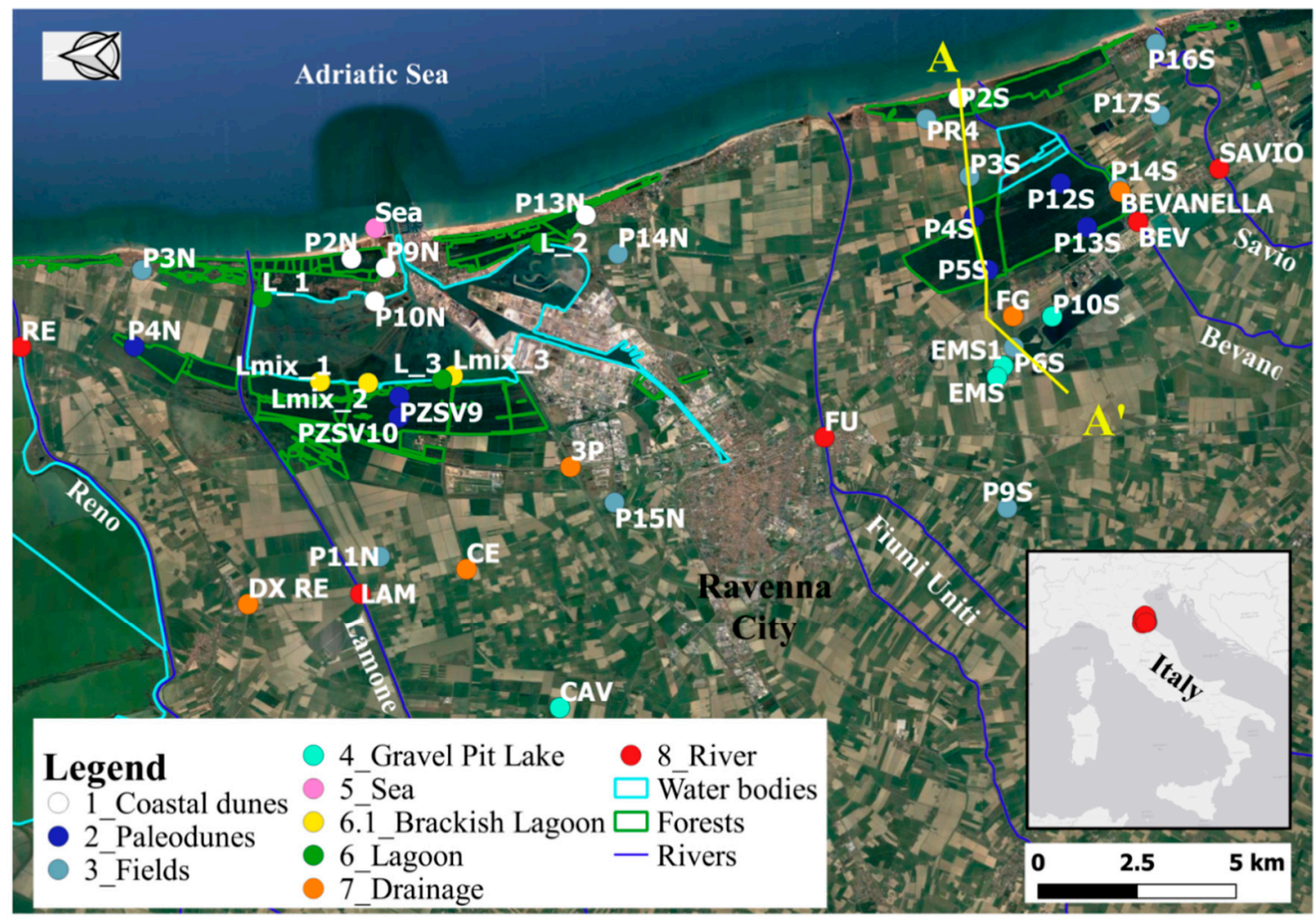

Figure 1. Location of surface and groundwater sampling points grouped by environment as classified by Mollema et al., 2013 [53]. Transect A-A' indicates the geological section shown in Figure 2. Background is a Google satellite by QuickMapService QGIS plugin. 


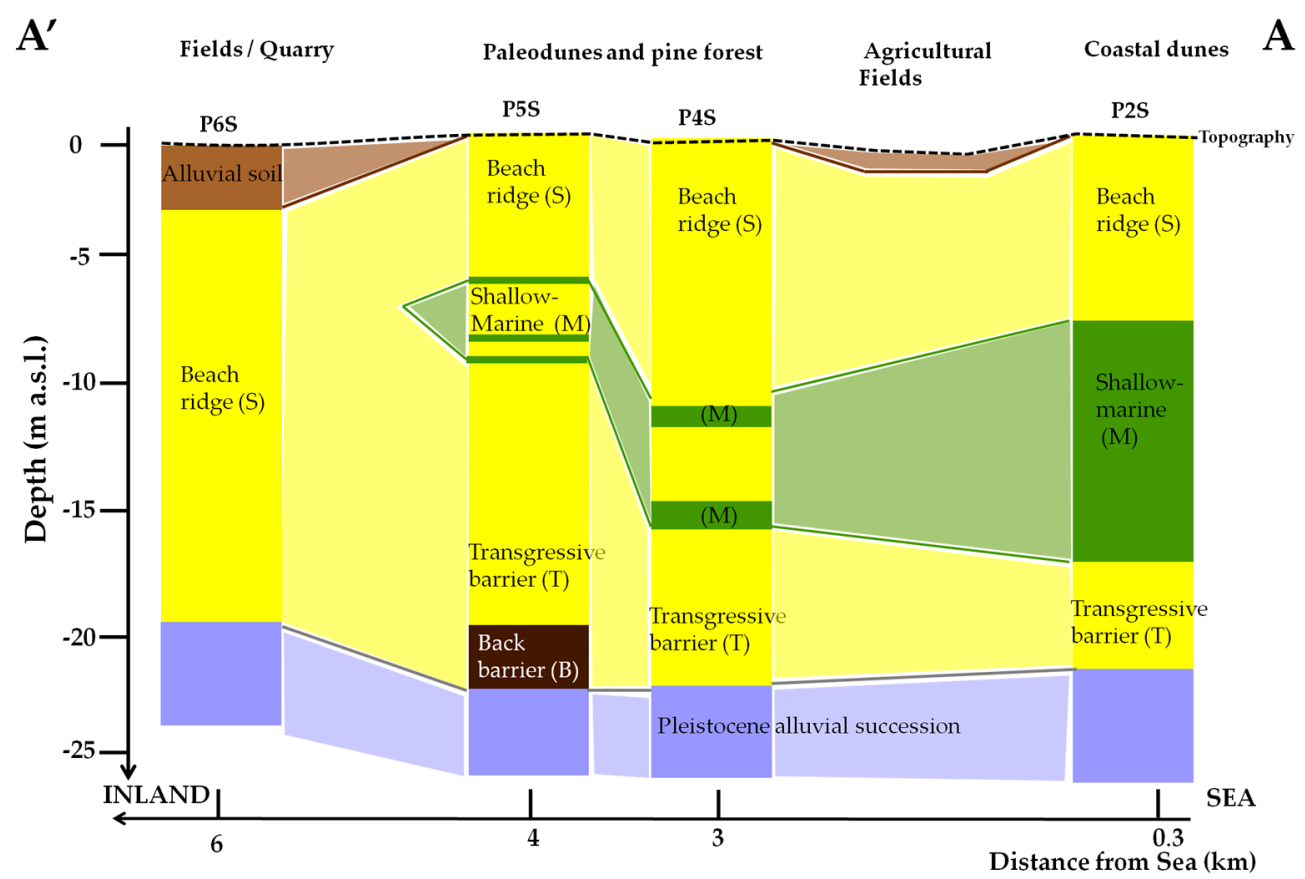

Figure 2. Geological section of the shallow coastal aquifer. Refer to Figure 1 for the section location. Depositional environments and interpolations are based on Amorosi et al. [50]. With respect to coastal dunes and paleodunes, the aquifer is phreatic, while it is semi-confined in agricultural fields and quarry environments.

A simplified east to west section of the area (Figure 1) shows narrow beaches and coastal dunes experiencing erosive trends [62]. Coastal dunes are broadly covered by a pine forest planted in the early 1900s to protect the inland crops from saline spray. Pialassa Baiona (saltwater lagoon) in the north and Ortazzo (freshwater wetland) in the south are the natural habitats left by the land reclamation that has characterized the study area since the last century. A paleodune belt is located on the western edge of the wetlands, covered by the historical San Vitale and Classe pine forest. Inland, agriculture activity becomes dominant, and several gravel pit lakes are found aligned in the NW-SE direction, indicating the boundary of the last marine transgression.

\subsection{Hydrogeological Settings}

The geological setting of the southern Po River floodplain is linked to Alpine and Apennine river sediments and marine sediments, controlled by the last eustatic and climatic fluctuations $[49,50,55]$. The last Holocene transgression (12 thousand years to present) is responsible of the entire deposition of the study aquifer. Starting from the last glacial lowstand, when the paleo-shoreline was about $250 \mathrm{~km}$ southeast of its current position [63], a rapid seaward migration of a barrier lagoon estuary system (16 and 5.5 thousand years BP) brought the paleo-shoreline $20-30 \mathrm{~km}$ inland with respect to the current position $[49,50]$. In response to the rapid sea level rise, deposition of transgressive sand and older shallow marine deposits occurred. During the highstand phase, sand spits and barrier islands grew, converting bays into confined lagoons where organic deposition occurred [50,55]. Then, progradation controlled by continental sedimentation proceeded, with the contemporary beach ridge's regression. In the most recent period, anthropic interventions (reclamation works and river diversions) controlled the recent depositional dynamics, until settling in its current position.

In the studied area, the resulting shallow coastal aquifer (Figure 2) is formed by two main sandy units, consisting of a medium-grained sand unit (from surface to $-10 \mathrm{~m}$ a.s.l) corresponding to beach ridge deposition, and a lower, fine-grained, thinner sand unit ( -15 to $-22 \mathrm{~m}$ a.s.l.), corresponding to transgressive deposition. In the middle of these two sandy units, a 10-m-thick unit of silty clay 
intercalations, rich in marine $\mathrm{OM}$, is present and corresponds to shallow marine deposition $[50,63]$. The aquifer stands on top of the Pleistocene alluvial succession, at $-23 \mathrm{~m}$ a.s.l. on average.

The surface hydrology includes Apennine Rivers (Reno, Lamone, Fiumi Uniti, Bevano and Savio) that in the alluvial plan flow toward the sea as hanging rivers. The territory is subdivided into many small watersheds, mostly mechanically drained through a dense network of drainage/irrigation channels, which direct water to pumping stations located 5-8 km from the sea [64]. The constant mechanical drainage through the year generates an atypical, inland-oriented hydraulic gradient, promoting saltwater intrusion $[53,61]$. Aquifer recharge from precipitation is poor and limited to the area where the aquifer is phreatic, namely, coastal dunes and paleodunes [16]. In these areas, ephemeral freshwater lenses exist, and they sustain freshwater habitats [6,65]. In agricultural areas, some episodic and uncontrolled aquifer recharge processes occur due to freshwater irrigation storage [19], or as direct infiltration from irrigation ditches [52].

\subsection{Environment Groups}

As presented by Mollema et al. [53], this complex coastal area has been divided into homogeneous sampling environment groups (called "environments" in the following) based on paleo-evolution and current management.

Although undergoing some modifications, in this paper the proposed sampling environment groups have been used for the discussion of GW and SW samples. Along an east-west profile and from GW to SW (Figure 1): (1) Coastal dunes represent the current dune belt, the highest topographic area and the recharge site of the shallow coastal aquifer. Where preserved, they are covered by pine forest and are included in the Po Delta Regional Park. (2) Paleodunes, located 3-4 km from the sea, correspond to the Medieval shoreline and they are covered by historical pine forest (San Vitale and Classe), and appear in the Regional Park.; the topography is generally higher than surrounding areas and the aquifer is phreatic. (3) Agricultural fields (in the following: fields) are characterized by low topography (from $-2.5 \mathrm{~m}$ a.s.l. to $0.5 \mathrm{~m}$ a.s.l.) and strong drainage to keep the land dry; the surface geology is often silty clay and the shallow aquifer is semiconfined. (4) Gravel pits correspond to a belt of lakes, are NW-SE oriented with exposed aquifer. Since 1950 they have been used for gravel exploitation, and they geographically correspond to the maximum marine transgressive phase, marking the limit between continental and marine sedimentation. (5) Generic seawater sample [66,67], used as a marine reference in the results and discussion. (6) Brackish Lagoon indicates the western ponds of the Pialassa Baiona, not directly open to the sea, where drainage water flows after the mechanical uplift made by the pumping station. Brackish water due to the mixing between drainage and marine water fills this ponds [60]. (6.1) Lagoon stands for the eastern ponds of the Pialassa Baiona wetland, directly connected to the sea thanks to the final part of the industrial harbor channel (Candiano Channel). The water is typically hypersaline, and historical pollution from the nearby industrial area is documented [68]. (7) Drainage indicates surface water coming from the drainage network that control land reclamation. (8) Rivers are surface water collected from the rivers flowing through the coastal area.

\section{Methods}

A total of 104 water samples were collected from groundwater wells (83 samples) and surface water bodies (21 samples) and their locations are shown in Figure 1. The GW samples come from 25 piezometers, while the SW samples are coastal lagoons (6), gravel pit lakes (4), drainage/irrigation ditches (5) and rivers (6) homogeneously distributed across the Ravenna coastal area, and representing all the environment groups previously defined and described by Mollema et al. (2013) [53]. Rivers and drainage samples were taken in the proximity of the study area with the aim of representing the water that really interacts with the local coastal aquifer.

For each groundwater well, a variable number of samples (2-5) was collected in November-December 2010 at different depths, i.e., at the water table, bottom, and in correspondence with significant aquifer layers (peat layers and fine-grained sediment layers) (supplementary materials 
Table S1). In wells where the aquifer is composed by two separated units, at least one sample per unit was collected. The wells are fully screened with depth, and the sampling collection was conducted with straddle packers after two times the water volume present in the sampling window $(30 \mathrm{~cm})$ of the 2 packers was purged.

Electrical conductivity, $\mathrm{pH}$, Eh, dissolved $\mathrm{O}_{2}$ and temperature were measured in the field with a multiparameter device XS PCD650 (Eutech Instruments Pte Ltd. part of Thermo Fisher Scientific Inc., Waltham, MA, USA) inserted in a flow cell to prevent rapid oxidation processes. Where a smell of $\mathrm{H}_{2} \mathrm{~S}$ was detected, the concentration of sulfide anions was measure using a portable spectrophotometer (Hach Company, Loveland, CO, USA). After the measurements of chemical-physical parameters, water samples were collected and filtered using a $0.45 \mu \mathrm{m}$ filter.

The water samples for cation and TEs determination were acidified with $\mathrm{HNO}_{3}$. All water samples were stored in pre-cleaned HDPE $250 \mathrm{~mL}$ plastic bottles and major elements $\left(\mathrm{Ca}^{2+}, \mathrm{Mg}^{2+}\right.$, $\mathrm{Na}^{+}, \mathrm{K}^{+}, \mathrm{Cl}^{-}, \mathrm{SO}_{4}{ }^{2-}, \mathrm{NO}_{3}{ }^{-}, \mathrm{HCO}_{3}{ }^{-}$and $\mathrm{Br}^{-}$) were analyzed within $24 \mathrm{~h}$ by the Research Centre C.R.S.A. of Med Ingegneria of Ravenna (Italy), following the standards set by the Italian National Environmental Agency, APAT-IRSA 2003. The ionic balance was calculated and samples with an ionic balance exceeding $5 \%$ were not included in the water type analysis.

The water samples for TEs analysis were diluted till TDS $<0.1 \%$, $\mathrm{pH}$ was stabilized below 2 with $1 \mathrm{~mL}$ of $\mathrm{HNO}_{3}$ and sent to Acme Analytical Laboratories Ltd., Vancouver, BC, Canada. Through Inductively Coupled Plasma-Atomic Emission Spectrometry/Inductively Coupled Plasma-Mass Spectrometry (ICP-AES/ICP-MS) Ag, As, B, Ba, Co, Cr, Cu, Fe, La, Li, Mn, Mo, Ni, Pb, Rb, Sb, Si, $\mathrm{Sr}, \mathrm{U}, \mathrm{V}$ and $\mathrm{Zn}$ have been analyzed. Although the analyzed elements were more than 70 , only elements with at least 30 measurements above the detection limits were included in the present dataset. Considering internal and external standards, accuracy and precision were better than $10 \%$ for all considered elements.

\section{Results and Discussion}

\subsection{Major Elements vs. Environment Groups}

In Figure 3, the physical and chemical parameters and the concentrations of major elements are summarized for each environment through box plots, while basic statistics are reported in Table S2. The lagoon samples, and some GW samples from coastal dune environments, reached salinity of $20 \mathrm{~g} / \mathrm{L}$, while the literature's data for seawater [66,67] show salinity of $33 \mathrm{~g} / \mathrm{L}$. The same samples denote the higher concentration for the saline-correlated major cations and anions, such as $\mathrm{Ca}^{2+}$, $\mathrm{Mg}^{2+}, \mathrm{Na}^{+}, \mathrm{K}^{+}, \mathrm{Cl}^{-}$and $\mathrm{SO}_{4}{ }^{2-}$. At the opposite end, rivers, drainage channels and brackish lagoons show the lowest salinity values, ranging from $0.5 \mathrm{~g} / \mathrm{L}$ in rivers and drainage channels up to $5 \mathrm{~g} / \mathrm{L}$ for brackish lagoon. Limiting to salinity, the geographic trend is well evident where coastal dunes have average salinity higher than paleodunes, fields and gravel pit environments, whose salinities decrease as we move inland (refer to study area section and Figure 1). This east-west salinization trend in the aquifer agrees with previous studies by Greggio et al. [18], Giambastiani et al. [51] and Cozzolino et al. [4] for similar and adjacent areas. Abundance sequences for the elements in groundwater are $\mathrm{Na}^{+}>\mathrm{Mg}^{2+}>\mathrm{Ca}^{2+}>\mathrm{K}^{+}$and $\mathrm{Cl}^{-}>\mathrm{HCO}_{3}{ }^{-} / \mathrm{SO}_{4}{ }^{2-}>\mathrm{Br}^{-}>\mathrm{NO}_{3}{ }^{-}$, for cations and anions, respectively. These findings agree with water-type classifications by Mollema et al. [53], who in the same area found $91 \%$ of water samples of the NaCl-type, $9 \%$ being freshwater with $\mathrm{Cl}^{-}<300 \mathrm{mg} / \mathrm{L}$, based on the water-type classification proposed by Stuyfzand [69]. 


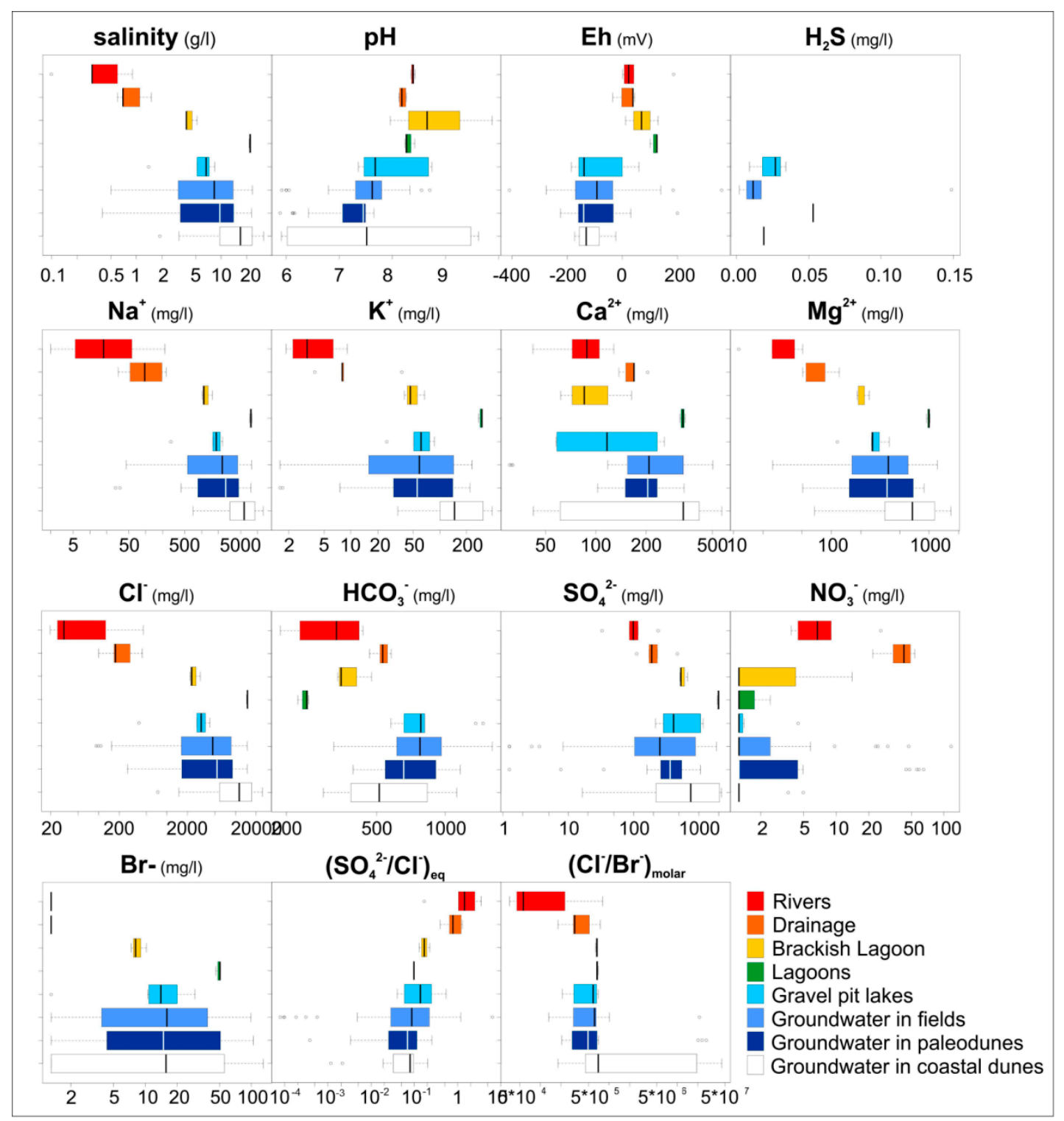

Figure 3. Box plot of major elements for the different environments. Concentrations are reported on a $\log$ scale and sea data refer to $[66,67]$.

Apart for some samples, $\mathrm{SW}$ and GW differ from each other in terms of $\mathrm{pH}$ and redox potential (Eh) (Figure 3). Thus, $\mathrm{pH}$ is constantly above 8 in SW, and averages 7.5 in GW samples. High pH variability is present in brackish lagoon, paleodunes and gravel pit environments. The Eh is constantly positive in samples of SW, while it is generally negative $(-100$ to $-200 \mathrm{mV})$ in $\mathrm{GW}$, indicating strong reducing conditions of groundwater in the aquifer, in line with outcomes from Colombani et al. [12] and Caschetto et al. [4] in the adjacent area. Some exceptions occur in shallow GW samples from fields and paleodunes environments, where positive redox values are related to the occurrence of groundwater recharge processes that constitute ephemeral freshwater lenses [6,52,53,70-72]. Shallow oxidizing conditions permit the presence of a nitrate concentration even higher than $50 \mathrm{mg} / \mathrm{L}$ (Italian National limit, D. Lgs. 152/06 [73]) in GW from fields and paleodunes, in line with the elevated concentration measured in drainage channels that drain the same territory.

Although the GW are characterized by high salinity values, the anoxic conditions affecting the aquifer promote a relevant variation of $\mathrm{SO}_{4}{ }^{2-}$ in coastal dunes, such as a strong decrease in sulphate concentrations with respect to the conservative freshwater/seawater mixing that is more evident in the field and paleodunes environments. The presence of $\mathrm{H}_{2} \mathrm{~S}$ in $\mathrm{GW}$ samples, with a 
maximum in paleodunes and field environments, confirms the reducing condition involving sulphate, as demonstrated by Colombani et al. [12] $30 \mathrm{~km}$ to the north. Despite the low salinity range (5 to $10 \mathrm{~g} / \mathrm{L}$ ), in gravel pit environments sulphate concentrations are elevated (box plot in Figure 3). Lastly, according to the main "Marnoso arenacea" formation present in the upper basin of the investigated river $[74,75]$, an increase of typical freshwater ions, such as $\mathrm{Ca}^{2+}$ and $\mathrm{HCO}_{3}{ }^{-}$, is visible in surface water, i.e., drainage and rivers samples.

The correlation matrix between major ions and salinity (Figure S1) shows good correlation values (>0.95) among salinity and $\mathrm{Na}^{+}, \mathrm{K}^{+}, \mathrm{Mg}^{2+}$ and $\mathrm{Cl}^{-}$. Given that the correlation of $\mathrm{SO}_{4}{ }^{2-}$ with other marine ions and salinity is weak (less than 0.6), further investigation is presented. The correlation of $\mathrm{Ca}^{2+}$ and $\mathrm{SO}_{4}{ }^{2-}$ is 0.75 , while the correlation between $\mathrm{SO}_{4}{ }^{2-}$ and alkalinity is negative. Although $\mathrm{Br}^{-}$ is considered a conservative anion [22], it shows a weak correlation with the salinity of marine ions, so more insights are presented and discussed.

\section{2. $\mathrm{SO}_{4}{ }^{2-}$ and $\mathrm{Br}^{-}$Anomalies under Organic Matter Degradation}

Figure 4 shows the $\mathrm{SO}_{4}{ }^{2-}$ concentration versus salinity values. The majority of the samples are located on the conservative mixing line, with rivers and sea as end-members (red line in Figure 4). Some samples show strong sulphate depletion, reaching the complete disappearance of $\mathrm{SO}_{4}{ }^{2-}$ from the solution. Samples depleted in $\mathrm{SO}_{4}{ }^{2-}$ mainly belong to fields and paleodunes environments, and are specifically evident all along the wells P11N, P4S and P15N, and the deepest samples of P4N, P2N, $\mathrm{P} 14 \mathrm{~N}$ and $\mathrm{P} 9 \mathrm{~N}$ (red rectangle in Figure 4). At the opposite end, $\mathrm{SO}_{4}{ }^{2-}$ enrichments are evident all along wells P10S and P16S, and in shallow samples of P6S and P4N, located in fields and gravel pit environments (brown rectangle in Figure 4).

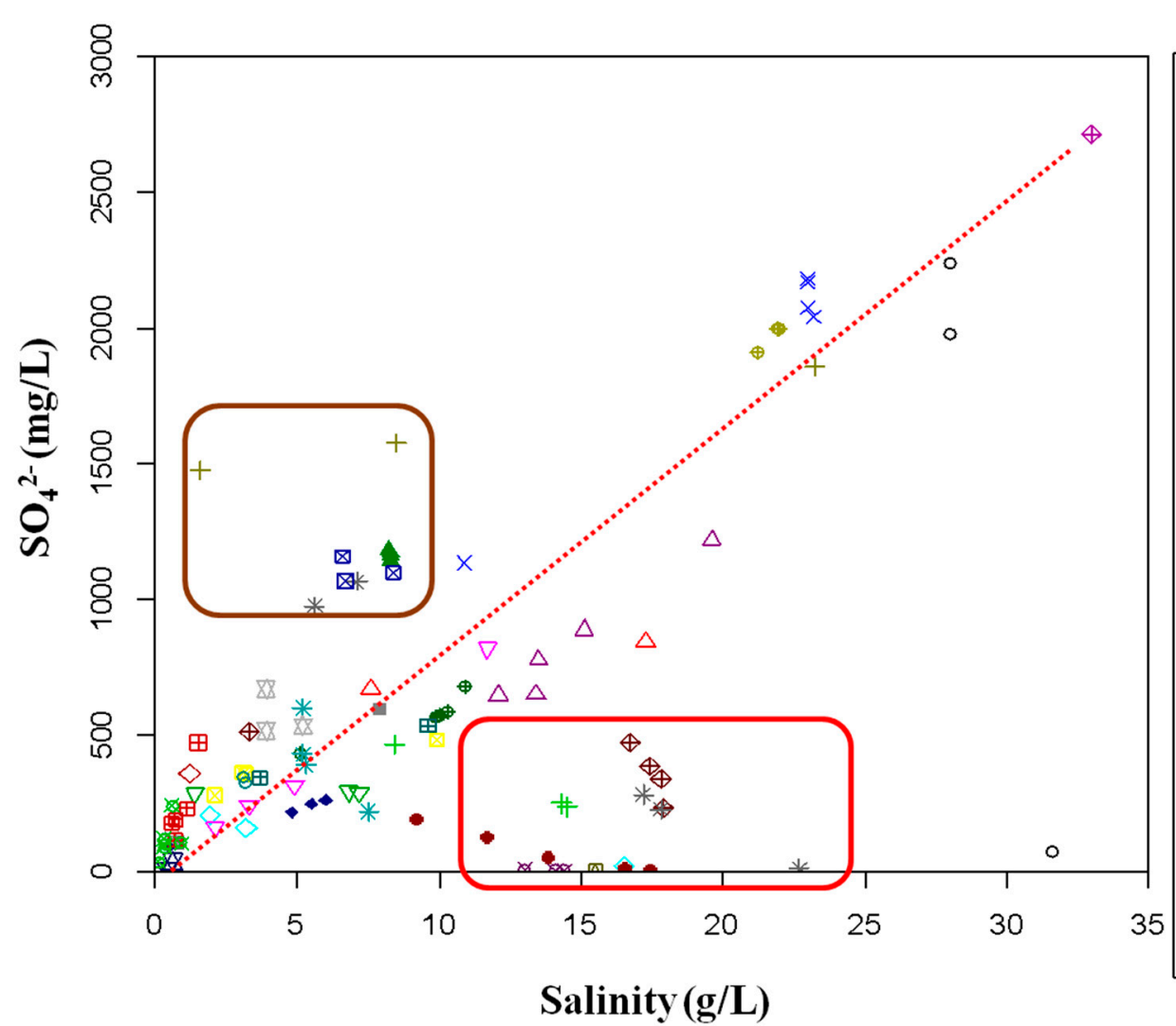

LEGEND

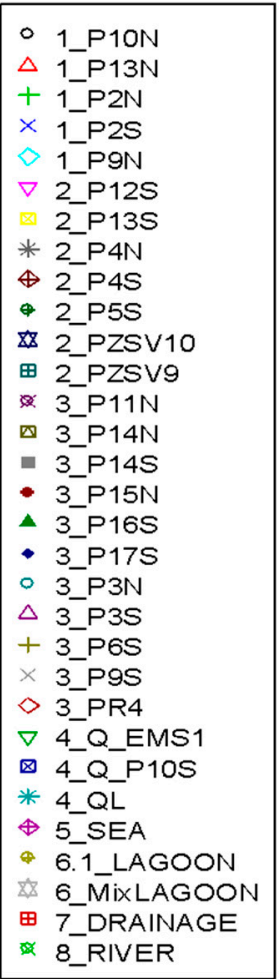

Figure 4. Binary plot of $\mathrm{SO}_{4}{ }^{2-}$ concentration vs. salinity for all samples. Samples are grouped by environments (1-8, refer to Section 2.2). 
Sulphate depletion is a process frequently observed in aquifers, where $\mathrm{SO}_{4}{ }^{2-}$ is related to seawater intrusion $[29,76,77]$. Although the sulphate decrease in groundwater could be attributed to both gypsum precipitation [29,32] and a reduction phenomenon [27], previous works in the same area excluded gypsum precipitation in light of the low saturation index, attributing the $\mathrm{SO}_{4}{ }^{2-}$ depletion exclusively to OM degradation in anoxic condition [51,53]. According to Jørgensen [78], the overall reaction

$$
2 \mathrm{CH}_{2} \mathrm{O}+\mathrm{SO}_{4}^{2-} \rightarrow 2 \mathrm{HCO}_{3}^{-}+\mathrm{H}_{2} \mathrm{~S}
$$

where $\mathrm{CH}_{2} \mathrm{O}$ stands for $\mathrm{OM}$, requires two fundamental conditions to occur: sufficient reactive $\mathrm{OM}$ in the aquifer, and anoxic conditions. Both conditions are widespread in the study area. Indeed, the last Holocene transgressive-regressive cycle deposited shallow marine deposits, organic reach layers and peat lenses in the aquifer $[49,50]$, which supply reactive organic carbon for the sulphate reduction [27]. Moreover, widespread anoxic conditions in GW are verified by the Eh box plot in Figure 3, and confirmed by the low hydraulic gradient acting in the aquifer [52] and the poor recharge rate (less than $20 \mathrm{~mm} / \mathrm{y}$ ), which is limited only to the phreatic portion of the aquifer, i.e., coastal and paleodunes [6,53].

As reported in Equation (1), $\mathrm{HCO}_{3}{ }^{-}$is one of the products of $\mathrm{OM}$ degradation under anoxic conditions. Considering also the $\mathrm{HCO}_{3}{ }^{-}$in the analysis, samples depleted in $\mathrm{SO}_{4}{ }^{2-}$ are contemporarily enriched in $\mathrm{HCO}_{3}{ }^{-}$(Figure S2), particularly P11N, P4S and P15N, which reach concentrations of $\mathrm{HCO}_{3}{ }^{-}$above $1500 \mathrm{mg} / \mathrm{L}$.

A particular behavior is observed for $\mathrm{Br}^{-}$where, as shown in Figure 5, bromide shows 3-4-fold enrichments, compared to the conservative saltwater-freshwater mixing line (Figure 5a). The samples with the highest $\mathrm{Br}^{-}$concentrations $\left(50-140 \mathrm{mg} / \mathrm{L}\right.$ ) appear in correspondence with $\mathrm{SO}_{4}{ }^{2-}$-depleted samples (Figure 5b).

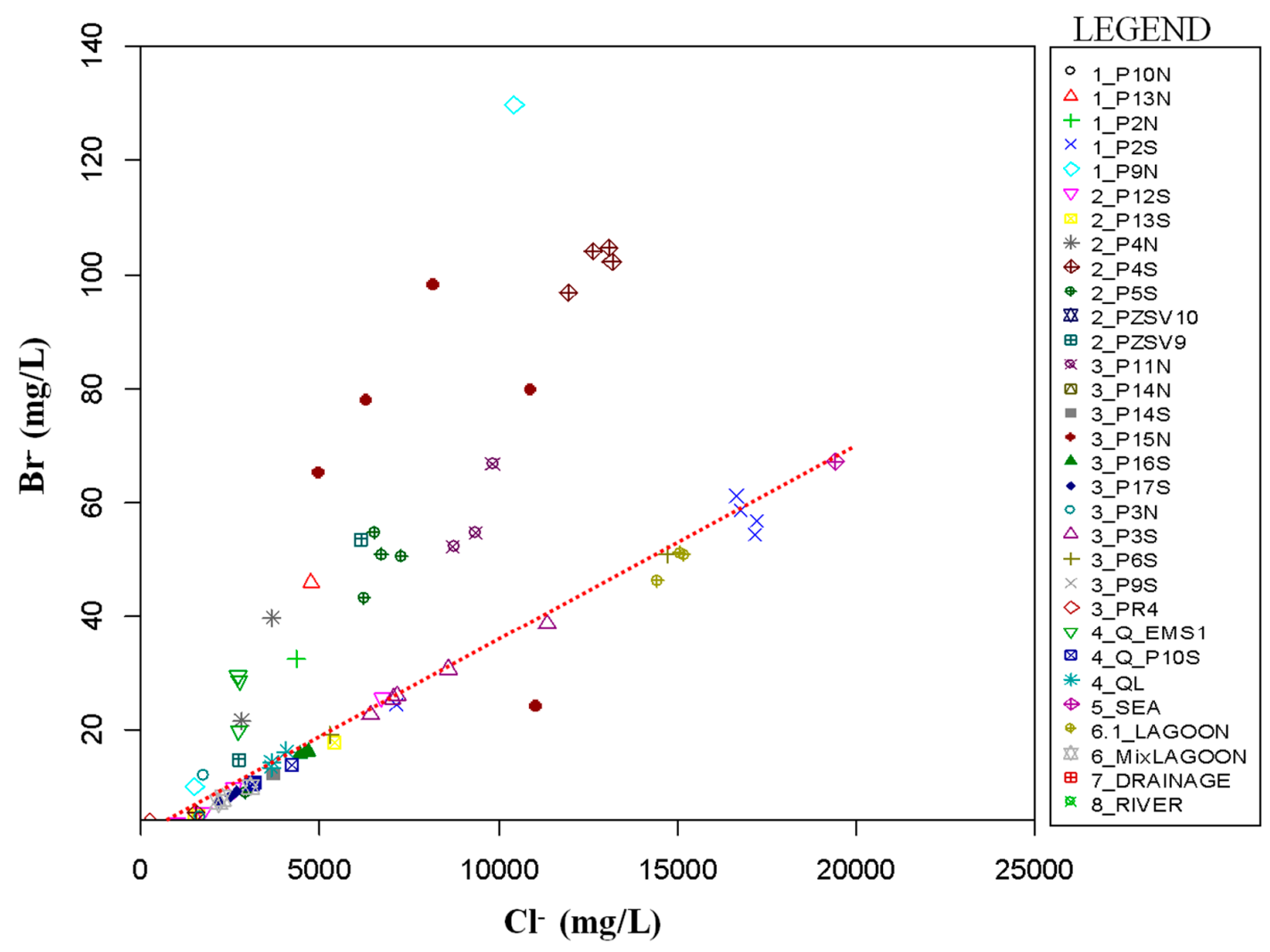

(a)

Figure 5. Cont. 


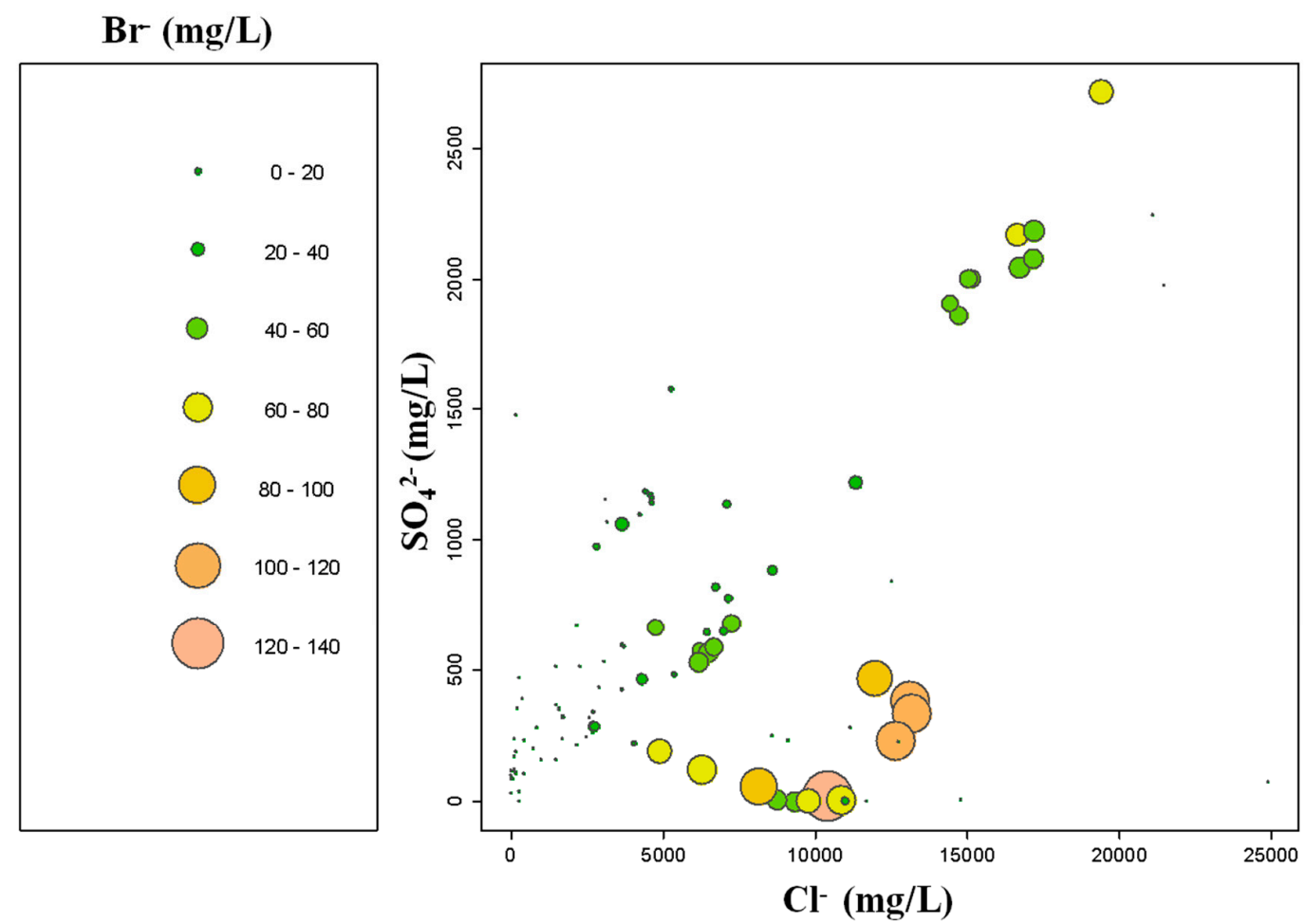

(b)

Figure 5. (a) Binary plot of $\mathrm{Br}^{-}$vs. $\mathrm{Cl}^{-}$concentrations of all samples grouped by environments (1-8); (b) Binary plot of $\mathrm{SO}_{4}{ }^{2-}$ vs. $\mathrm{Cl}^{-}$; symbols are proportional to $\mathrm{Br}^{-}$concentrations.

Although $\mathrm{Br}^{-}$was supposed to be an unreactive species, and it is often used as a conservative tracer in hydrogeological studies, recently the scientific community has revealed biogeochemical cycling of $\mathrm{Br}^{-}$between organic and inorganic forms [79]. In particular, OM of marine origin is reported to be a sink for $\mathrm{Br}^{-}$[80]. In the studied aquifer, the presence of organic reach layers deposited during the last Holocene cycle, along with $\mathrm{OM}$ degradation processes guided by $\mathrm{SO}_{4}{ }^{2-}$ reduction, bring in solution relevant amount of bromide. Similar enrichments in pore water due to debromination processes have been reported for marine sediments and soils encountering decomposition of OM during diagenesis [33,79,81-84]. Li et al. [23], for general processes, and Mollema et al. [53] for the same area, justify the low $\mathrm{Cl}^{-} / \mathrm{Br}^{-}$weight ratios as being due to halite precipitation/dissolution cycles for the most shallow GW samples, but in our case, the $\mathrm{Br}^{-}$enrichments occurs in the deepest portion of the aquifer, and does not refer to the same process described in Mollema et al. [53]. In an adjacent area, Colombani et al. [12] showed quite peculiar values of 900 for the $\mathrm{Cl}^{-} / \mathrm{Br}^{-}$molar ratio, justifying them via the presence of $\mathrm{OM}$ and peat layers acting as a sink for $\mathrm{Br}^{-}$in groundwater under high seepage values.

Using the diagram's $\mathrm{Cl}^{-} / \mathrm{Br}^{-}$molar ratio vs. the $\mathrm{Cl}^{-} \mathrm{mg} / \mathrm{L}$ proposed by Alcalá and Custodio [22] as reference for GW salinity origin (Figure 6), the majority of GW samples fall into the area identified as seawater intrusion. Some of them (wells P14S and P17S) have $\mathrm{Cl}^{-}$concentrations around $100 \mathrm{mg} / \mathrm{L}$, and $\mathrm{Cl}^{-} / \mathrm{Br}^{-}$ratios below 300, falling between the coastal area and the agricultural pollution phenomenon [15]. A second group of GW samples falls close to the domain identified as pollution by both agriculture and septic waste. This group includes six shallow GW samples, two of them from the P9N well, which is located near a summer camping area whose septic water could infiltrate during its operative period, generating a depletion of the ratio, as reported by Li et al. [23]. Three samples from the P10S well (lagoon environment) show the highest $\mathrm{Cl}^{-} / \mathrm{Br}^{-}$ratio, with values around 40,000, compatible with repeated cycles of natural halite dissolution. The last group of the GW sample, with a $\mathrm{Cl}^{-} / \mathrm{Br}^{-}$ratio below 300 and a high $\mathrm{Cl}^{-}$concentration (about 10,000 mg/L), falls 
in an area where no processes have been highlighted by Alcalá and Custodio [22]. These samples (indicated by the red box in Figure 6) have an $\mathrm{SO}_{4}{ }^{2-} / \mathrm{Cl}^{-}$equivalent ratio extremely low, well below $0.1 \pm 0.02$, which is identified as Adriatic seawater's value by Colombani et al. [12], indicating strong $\mathrm{SO}_{4}{ }^{2-}$ reduction process. These GW samples belong to wells P11N, P15N, P4S and P5S (Figure S3), already indicated as $\mathrm{SO}_{4}{ }^{2-}$-depleted in Figure 4, suggesting a new process to be considered in the diagram where strong OM degradation occurs in organic-reach sediment deposits, bringing a high amount of $\mathrm{Br}^{-}$into the solution.

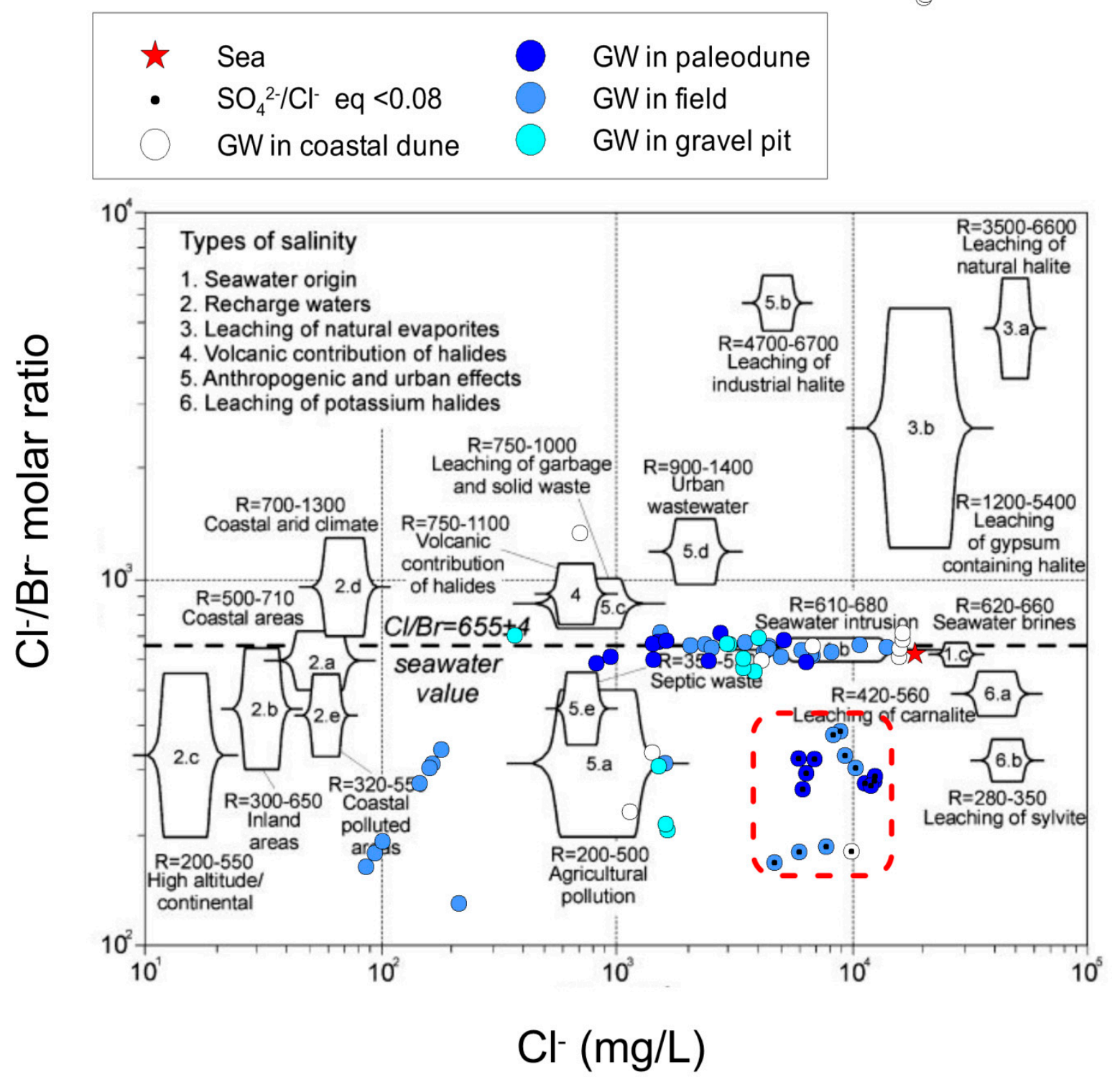

Figure 6. Diagram of $\mathrm{Cl}^{-} / \mathrm{Br}^{-}$molar ratio vs. $\mathrm{Cl}^{-}(\mathrm{mg} / \mathrm{L})$ for all groundwater samples. Black and white background image is the diagram of $\mathrm{Cl}^{-} / \mathrm{Br}^{-}$molar ratio vs. $\mathrm{Cl}^{-}(\mathrm{mg} / \mathrm{L})$ proposed by Alcalá and Custodio [22] to identify the salinity's origin. The red box is enlarged in Figure S3 to label each sample.

Regarding the $\mathrm{SO}_{4}{ }^{2-}$ enrichments at low chloride concentrations noted in some samples (Figure 4), specifically the P10S and P16S wells and shallow samples P6S and P4N, the most probable explanation is the pyrite oxidation guided by $\mathrm{O}_{2}$-rich water reaching the anoxic aquifer layers, or water table fluctuation that exposes the saturated portion of the aquifer to unsaturated conditions. The gravel pit excavation activities operating close to wells P10S and P6S reasonably explain the exposure of the 
deepest anoxic aquifer layers to $\mathrm{O}_{2}$-rich waters, and justify the pyrite oxidation and $\mathrm{SO}_{4}{ }^{2-}$ enrichments. Instead, the P4N and P16S wells are located close to rivers, and their measured Eh values verify a deep infiltration of $\mathrm{O}_{2}$-rich water promoting pyrite oxidation $[15,51,53,85]$.

The alternative hypothesis of gypsum dissolution is discarded due to the negative saturation index values calculated in the area for gypsum [15,51]. Caschetto et al. [4], in an adjacent area, showed the frequent occurrence of pyrite oxidation, and in an agricultural area the oxidation could also be guided by nitrates [4].

\subsection{Trace Elements vs. Environment Groups}

The TEs concentrations for all water samples are shown in the box plots in Figure 7, while basic statistics, average sea TEs concentration [66,67], Italian National Environmental limits and maximum recommended concentrations for irrigation water are presented in Table 1.

Boron, $\mathrm{Fe}, \mathrm{Si}$ and $\mathrm{Sr}$ are the most abundant, with median values reaching above $1 \mathrm{mg} / \mathrm{L}$. Among the previous TEs, Fe has the widest variability, ranging from 300 to $6000 \mu \mathrm{g} / \mathrm{L}$. Ba, Mn and $\mathrm{Zn}$ have median values between 100 and $1000 \mu \mathrm{g} / \mathrm{L}$. Co, La and Sb have median values equal to or below $1 \mu \mathrm{g} / \mathrm{L}$, and $\mathrm{Ag}, \mathrm{As}, \mathrm{Cr}, \mathrm{Cu}, \mathrm{Li} \mathrm{Mo}, \mathrm{Ni}, \mathrm{Pb}, \mathrm{Rb}, \mathrm{U}$ and $\mathrm{V}$ show medians between 1 and $100 \mu \mathrm{g} / \mathrm{L}$.

It can be noted that in some cases the recommended values for irrigation (green dotted line in Figure 7) are lower than the more restrictive ones for drinking water (red line in Figure 7), as in the case of $\mathrm{Co}, \mathrm{Cu}, \mathrm{Mo}$ and $\mathrm{Zn}$. For irrigation purpose, few samples exceed the recommended maximum values for $\mathrm{Fe}, \mathrm{Mo}, \mathrm{Ni}$ and $\mathrm{Zn}$; instead, almost $75 \%$ of the samples have too-high Mn concentrations for irrigation purposes. Problems related to $\mathrm{Fe}$ and $\mathrm{Mn}$ concentrations in irrigation waters are well documented by Bortolini et al. [86] for the entire Mediterranean region.

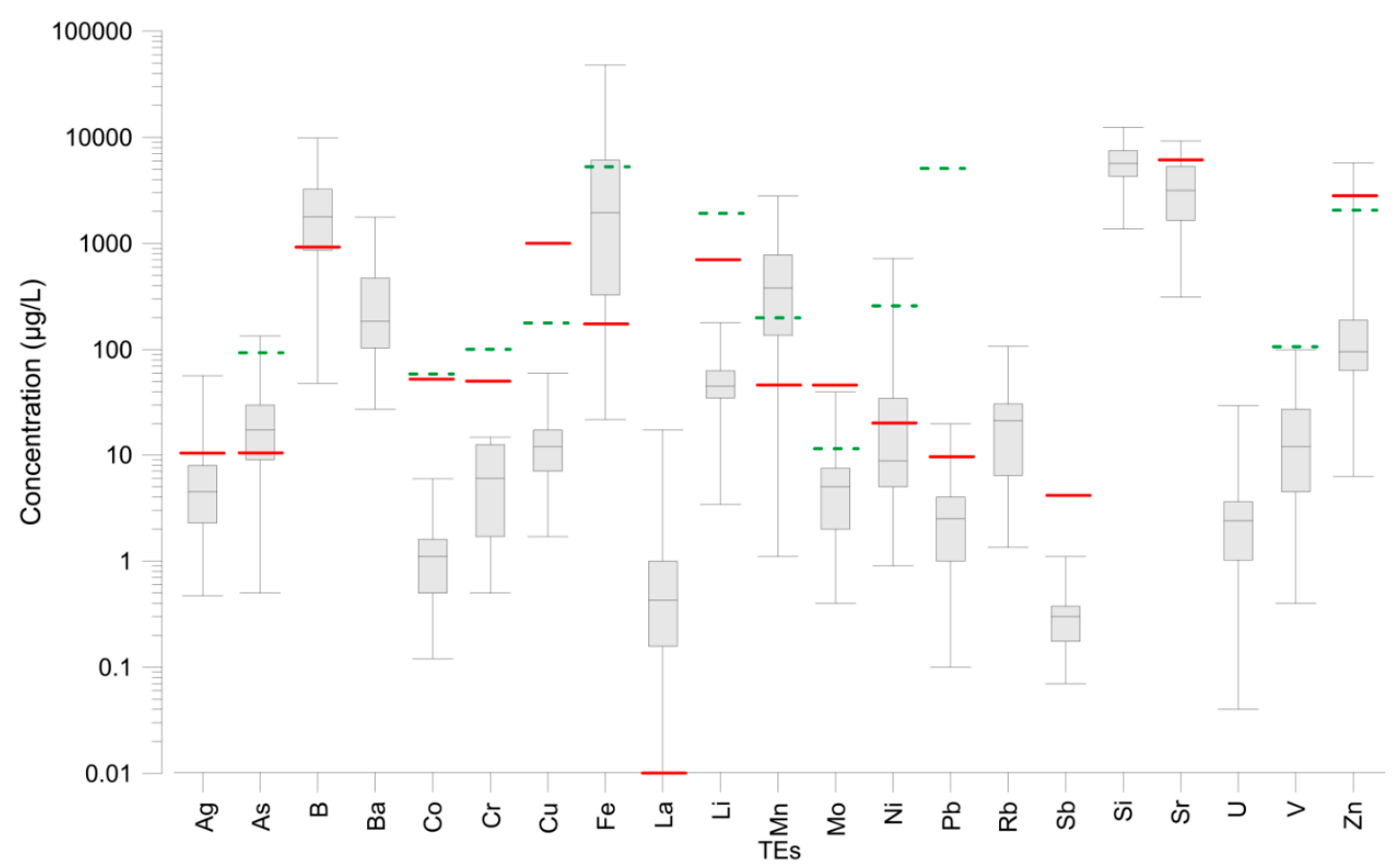

Figure 7. Box plots of TEs concentrations of all water samples $(n=104)$; red lines represent the limits posed by Italian Environmental Legislation 152/06 [73] and, when not present, other international sources as indicated in Table 1. Green dotted lines stand for recommended maximum values for irrigation water as reported by FAO [87]. Refer to Table 1 for numerical values. 
Table 1. Statistic of TEs concentrations of all water samples. Also listed are also the normative limits based on Italian Environmental Legislation 152/06 [73] and recommended concentration for irrigation by FAO [87]. Concentrations are in $\mu \mathrm{g} / \mathrm{L} ;$ "d.l." stands for detection limits. Bold concentration values indicate samples which exceed the most restrictive limits.

\begin{tabular}{|c|c|c|c|c|c|c|c|c|c|c|c|c|c|c|c|}
\hline 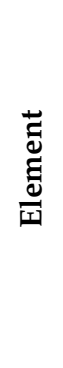 & ن் & 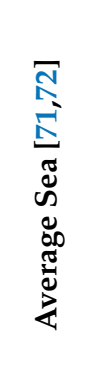 & $\begin{array}{l}\dot{0} \\
\stackrel{0}{0} \\
0 \\
\Rightarrow\end{array}$ & $\begin{array}{l}\dot{\vec{\theta}} \\
\hat{0} \\
\dot{D} \\
\dot{0}\end{array}$ & $\sum_{\Sigma}^{\Xi}$ & 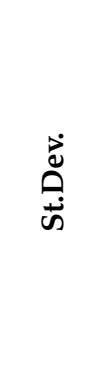 & $\stackrel{\Xi}{\Sigma}$ & $\stackrel{i n}{N}$ & 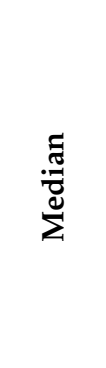 & in & $\stackrel{\circlearrowright}{\Xi}$ & 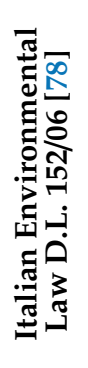 & 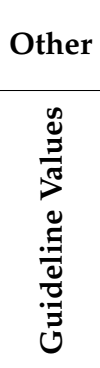 & 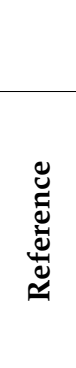 & 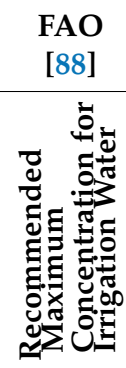 \\
\hline As & 0.5 & 2.6 & 104 & 95 & 19.6 & 21.0 & $<0.5$ & 5.5 & 15 & 28 & 134.4 & 10 & & & 100 \\
\hline B & 5 & 4450 & 104 & 104 & 2292 & 1907 & 48 & 860 & 1780 & 3300 & 9875 & 1000 & & & \\
\hline $\mathrm{Ba}$ & 0.05 & 21 & 104 & 104 & 331 & 343 & 13 & 104 & 184 & 471.5 & 1768 & & & & \\
\hline $\mathrm{Co}$ & 0.02 & 0.39 & 104 & 84 & 1.1 & 1.2 & $<0.02$ & 0.14 & 0.75 & 1.5 & 5.95 & 50 & & & 50 \\
\hline $\mathrm{Cr}$ & 0.5 & 0.2 & 104 & 37 & 2.5 & 4.7 & $<0.5$ & $<0.5$ & $<0.5$ & 2.5 & 20 & 50 & & & 100 \\
\hline $\mathrm{Cu}$ & 0.1 & 0.9 & 104 & 103 & 13.3 & 10.9 & $<0.1$ & 7 & 10 & 17 & 60 & 1000 & & & 200 \\
\hline Mo & 0.1 & 10 & 104 & 92 & 5.1 & 5.9 & $<0.1$ & 1.1 & 4 & 7 & 40 & & 50 & [91] & 10 \\
\hline $\mathrm{Ni}$ & 0.2 & 6.6 & 104 & 82 & 33.6 & 101.3 & $<0.2$ & 1.6 & 6 & 20 & 722.5 & 20 & & & 200 \\
\hline $\mathrm{Pb}$ & 0.1 & 0.03 & 104 & 73 & 2.4 & 3.8 & $<0.1$ & $<0.1$ & 1.3 & 3 & 20 & 10 & & & 5000 \\
\hline $\mathrm{Rb}$ & 0.01 & 120 & 104 & 104 & 24.1 & 23.2 & 1.34 & 6.4 & 21.5 & 30.75 & 120 & & & & \\
\hline $\mathrm{Sb}$ & 0.05 & 0.24 & 104 & 32 & 0.1 & 0.2 & $<0.05$ & $<0.05$ & $<0.05$ & 0.15 & 1.1 & 5 & & & \\
\hline $\mathrm{Si}$ & 40 & 2900 & 104 & 99 & 5374 & 2679 & $<40$ & 3540 & 5475 & 7490 & 12400 & & & & \\
\hline $\mathrm{Sr}$ & 0.01 & 8100 & 104 & 104 & 3525 & 2161 & 311.7 & 1654 & 3159.5 & 5325 & 9217.5 & & 7000 & [92] & \\
\hline $\mathrm{U}$ & 0.02 & 3.3 & 104 & 75 & 2.6 & 4.2 & $<0.02$ & $<0.02$ & 1.45 & 3.1 & 29.7 & & & & \\
\hline $\mathrm{V}$ & 0.2 & 1.9 & 104 & 104 & 16.5 & 15.4 & $<0.2$ & 4 & 12 & 27.5 & 100 & & & & 100 \\
\hline $\mathrm{Zn}$ & 0.5 & 5 & 104 & 102 & 242.1 & 646.5 & $<0.5$ & 60 & 95 & 180 & 5730 & 3000 & & & 2000 \\
\hline
\end{tabular}


The box plots in Figure 8 show that GW is generally more enriched in trace elements than SW, with the exceptions of $\mathrm{La}, \mathrm{Sb}$ and $\mathrm{U}$ concentrations, which are similar among SW and GW. Observing the box plot also allows us to discriminate between two separate groups: (I) TEs with concentrations determined by conservative mixing between fresh and seawater, where concentrations in open-to-sea lagoons are higher than the other samples. (II) TEs with concentrations resulting from water-sediment interaction processes, like ion exchange, mineral dissolution and precipitation, and redox reactions also involving OM; in this group GW concentrations are several orders of magnitude higher than in the sea. Many of the literature reviews describe these processes as determinant for GW and SW hydrochemistry in coastal areas [25,77,93]; a conservative mixing is evident for $\mathrm{B}, \mathrm{Li}, \mathrm{Rb}$ and $\mathrm{Sr}$, and water-sediment interaction processes justify $\mathrm{Ag}, \mathrm{As}, \mathrm{Ba}, \mathrm{Co}, \mathrm{Cr}, \mathrm{Cu}, \mathrm{Fe}, \mathrm{La}, \mathrm{Mn}, \mathrm{Mo}, \mathrm{Ni}, \mathrm{Pb}, \mathrm{Sb}, \mathrm{Si}, \mathrm{U}, \mathrm{V}$ and Zn abundance.

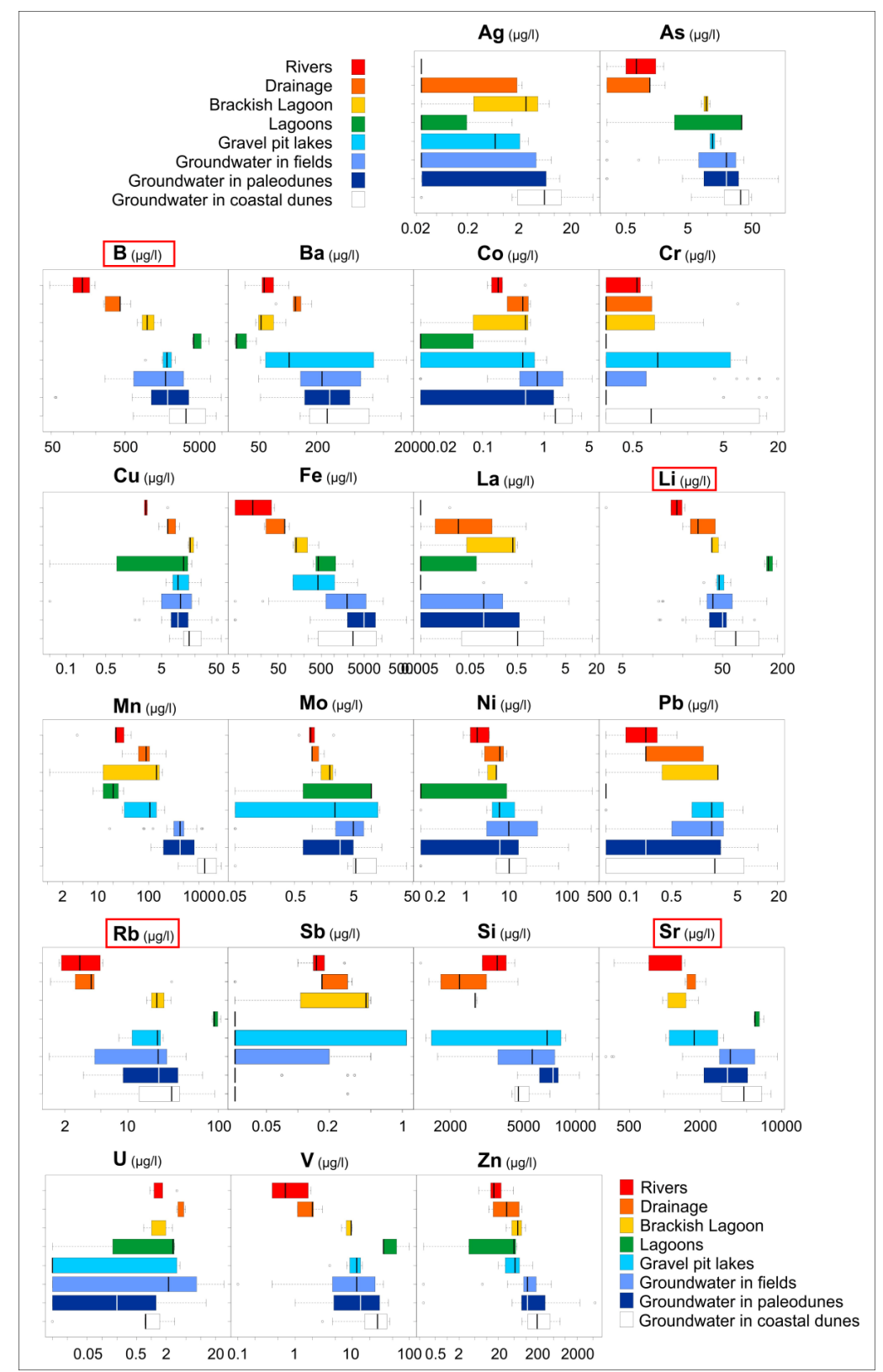

Figure 8. Box plots of TEs concentrations of all water samples grouped by environments. Environment groups order shows surface water from fresh (Rivers) to saline (Lagoons) and then groundwater from inland (Gravel pit) to sea (Groundwater in coastal dune). TEs are in alphabetic order. B, Li, $\mathrm{Rb}$ and $\mathrm{Sr}$ are highlighted by red boxes to indicate their conservative behavior. 


\subsubsection{Uranium, Antimony and Lanthanum}

Observing box plots in Figure 8, La, Sb and U exhibit comparable concentrations in GW and SW, with peaks of $\mathrm{Sb}$ in the gravel pit environment, while $\mathrm{U}$ enrichments occur in drainage channels and in fields. When present in $\mathrm{GW}, \mathrm{La}, \mathrm{U}$ and $\mathrm{Sb}$ are found in shallow samples, related to oxic aquifer layers, and their concentrations do not seem to be correlated with each other.

Gravel pit lakes and drainage water have $U$ concentrations in the range of $3-5 \mu \mathrm{g} / \mathrm{L}$, but water from field environments shows U concentrations from 10 to $30 \mu \mathrm{g} / \mathrm{L}$, specifically in P6S, P16S and P17S wells. The abundance in the shallow portion of the aquifer justifies the presence of $U$ in the dense network of drainage channels operating in the study area [52]. As reported by Liesch et al. [93], apart from natural bedrock, uranium is related to chemical fertilizer supply in intensive agricultural areas, generating implications for their over application [94]. Although U tends to adsorb into OM [95], its abundance in GW from field environments indicates agricultural practices as the main U source [36].

Antimony has peak of concentrations within gravel pit lake waters $(1.1 \mu \mathrm{g} / \mathrm{L})$, but it is also present in rivers, drainage and lagoons, ranging from 0.1 to $0.5 \mu \mathrm{g} / \mathrm{L}$. In GW, it is present exclusively in shallow oxic layers. As reported by Mollema et al. [15], being an oxyanion soluble at high $\mathrm{pH}, \mathrm{Sb}$ is present in solution in the quarry environment, and its origin is linked to organic-reach sediment layers that release $\mathrm{Sb}$ in solution form through anaerobic degradation [42,96]. Antimony in shallow GW from field environments is sourced by irrigation water supplied by drainage channels during the growing season.

Lanthanum ranges from 1 to $5 \mu \mathrm{g} / \mathrm{L}$ in SW and GW, with a peak of $16 \mu \mathrm{g} / \mathrm{L}$ in P10N well.

All samples containing $\mathrm{La}$ are above the guideline values indicated by the Australian Government [89] (Figure 7 and Table 1). If La abundance in SW is related to Al, phosphate and dissolved organic carbon [97], the peak of La detected in GW could be related to the reduction condition that is widespread in the aquifer. Cidu et al. [98] measured the same range of La in groundwater for the same area, and motivated the enrichments with the chemical reduction of Fe-oxy-hydroxides.

\subsubsection{TEs with Conservative Mixing Behavior}

Boron, $\mathrm{Li}, \mathrm{Rb}$ and $\mathrm{Sr}$ have the highest concentrations in seawater and in lagoon basins connected to the sea. For the same TEs, SW (rivers, drainage and brackish lagoon) show the absence or lower concentrations than in GW (coastal dunes, paleodunes, fields and gravel pit). Moreover, GW shows a geographical east-west decreasing trend in concentration ranges, with coastal dune greater than paleodunes, which is in turn greater than fields and gravel pit, which agrees with distance to the sea.

Boron concentrations exceed Italian Environment Legislation [73]. It has a high Pearson correlation coefficient (0.83) (refer to Figure S4) with chlorine, confirming its seawater intrusion origin [99], although some enrichments are evident. Specifically, elevated B concentrations occur in shallow samples of the P3S well, and in several of the deepest samples of coastal and paleodunes environments. Due to its location, the abundance in the P3S well can be explained by both pig slurry and other animal-derived fertilizers, which are seasonally added to soil [37], and B desorption from mineral surfaces during freshening processes, occurring in the aquifers previously invaded by saltwater [100-102]. The elevated $B$ concentration in the deepest samples ( -20 to $-25 \mathrm{~m}$ below ground) could be related to the dolomite dissolution included in transgressive sand [49], as already noted by Colombani et al. [103].

Rubidium and Sr are well correlated with chlorine, 0.86 and 0.84 respectively (Figure S4), describing a conservative mixing in the aquifer, as noted by Mollema et al. [15] for the same area. Differently from previous TEs, $\mathrm{Li}$ shows the lowest correlation with $\mathrm{Cl}^{-}$, and at a $\mathrm{Cl}^{-}$concentration between $5000 \mathrm{mg} / \mathrm{L}$ and $15,000 \mathrm{mg} / \mathrm{L} \mathrm{Li}$ is depleted by $50 \%$, compared to the conservative mixing (Figure 9). Most of the samples with Li depletion correspond with abundant $\mathrm{OM}$ and sulphate reduction (refer to Section 4.2). This Li depletion is evident with respect to all major cations. Since sorption is the most important process in controlling Li concentration, it disappears from the solution during seawater intrusion [24,101], as well as when the clay layer and OM are present in the aquifer. Excluding the samples where $\mathrm{SO}_{4}{ }^{2-}$ reduction is an ongoing process, $\mathrm{Li}$ depletion indicates salinization processes at P2S, P3S and P5S, as confirmed by Greggio et al. [18] and Mollema et al. [53]. At the opposite 
end, a few samples, which belong to the field environment (PR4, P16S, P17S and P6S), display Li enrichments. P16S and P6S have already been presented as freshwater recharge sites, while PR4 borders an intensive irrigated orchard site. Previous studies indicate increasing Li concentration during freshening processes [104] and organic amendment [105].

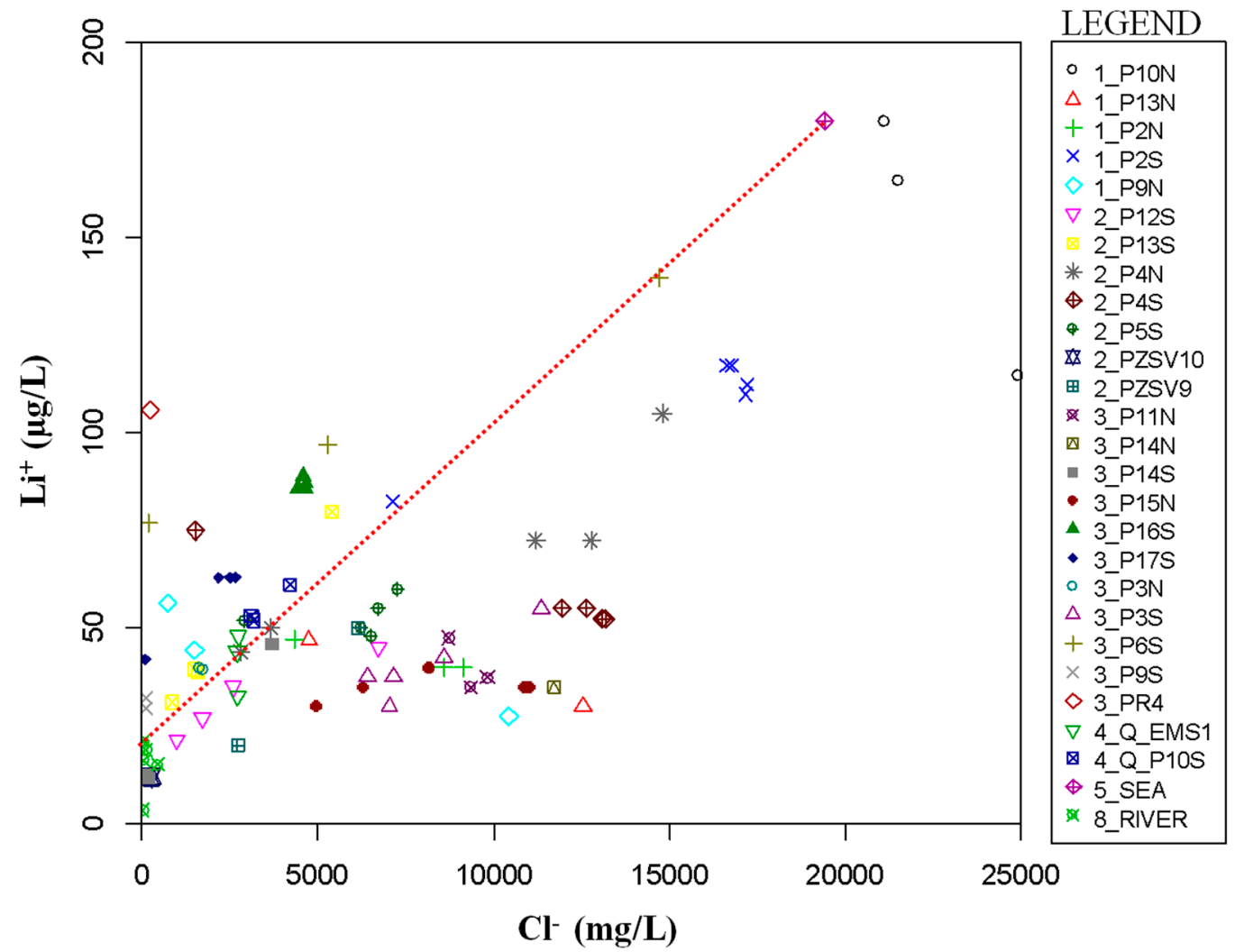

Figure 9. Scatterplot $\mathrm{Li}^{+}$vs. $\mathrm{Cl}^{-}$of all groundwater samples. Red dotted line indicates conservative mixing between rivers and sea used as end members.

\subsubsection{TEs Depending on Water-Sediment Interaction Processes}

This second group of TEs, including $\mathrm{Ag}$, $\mathrm{As}, \mathrm{Ba}, \mathrm{Co}, \mathrm{Cr}, \mathrm{Cu}, \mathrm{Fe}, \mathrm{Mn}, \mathrm{Mo}, \mathrm{Ni}, \mathrm{Pb}, \mathrm{Si}, \mathrm{V}$ and $\mathrm{Zn}$, depends on water-sediment interaction processes; their ranges of concentration in GW are higher than those for all SW, including both fresh (rivers, drainage and brackish lagoon) and saline lagoons (Figure 8). Enrichments below 10 times the $\mathrm{SW}$ concentration are notable for $\mathrm{Ag}$, $\mathrm{As}, \mathrm{Co}, \mathrm{Cr}, \mathrm{Mo}, \mathrm{Pb}, \mathrm{Si}$ and $\mathrm{V}$, while more than 100-fold enrichments are seen in $\mathrm{GW}$, in comparison with SW for $\mathrm{Ba}, \mathrm{Fe}, \mathrm{Mn}$, $\mathrm{Ni}$ and $\mathrm{Zn}$.

The elevated concentration of $\mathrm{Ba}$ and $\mathrm{Si}$ are indicators of strong water-sediment interactions, with alterations of the main sandy minerals (phyllosilicates and silicates) constituting the aquifer and long residence time of GW [106,107].

The widespread abundance of Fe and $\mathrm{Mn}$ in GW (concentrations up to 50 and $3 \mathrm{mg} / \mathrm{L}$, respectively; Table 1) derived from the redox reactions occurring in the aquifer, where abundant levels of $\mathrm{OM}$ and Fe- and Mn-hydroxides under anoxic conditions promote the OM degradation and the contemporary $\mathrm{Fe}$ and Mn reduction. Samples from the recently deposited paleodunes environment (P2S, P10N, $\mathrm{P} 13 \mathrm{~N}$ and $\mathrm{P} 2 \mathrm{~N}$ ) are enriched in Mn with low Fe concentrations, whereas when moving inland the Fe concentration becomes dominant, indicating stronger anoxic conditions (refer to low Eh value in Figure 3) and longer residence time for GW under paleodune and fields environments (Figure S5). As reported by Lovley [108], the reduction of $\mathrm{Fe}^{3+}$ and $\mathrm{Mn}^{4+}$ oxides to soluble $\mathrm{Fe}^{2+}$ and $\mathrm{Mn}^{2+}$ forms is one of the most important geochemical reactions in anaerobic environments, with regards to explaining the high concentration of dissolved Fe and $\mathrm{Mn}$ in water. These processes are part of a sequential 
reduction chain that leads to OM degradation through different species as electron acceptors with a specific order, depending on Eh values: nitrate, manganese, iron, sulphate, and finally fermentation leading to the production of $\mathrm{CH}_{4}[28,32]$. The $\mathrm{OM}$ degradation is also confirmed by $\mathrm{SO}_{4}{ }^{2-}$ depletion in several wells (refer to Section 4.2), and the presence of methane gas during the field campaign (not presented here). Similar findings are documented in the adjacent Ferrara coastal aquifer through sulfur isotopes by Caschetto et al. [4].

The remaining TEs can reach the solution stage through OM oxidation via the reduction of $\mathrm{Mn}$ and Fe hydroxides, and later by sulphate reduction, ion exchange with sediments (in particular clay minerals), and OM or mineral dissolution, but some TEs can also disappear from the solution through mineral precipitation [25].

Applying the Pearson correlation to water-sediment TEs, low correlation values are shown for the majority of the combinations (refer to Figure S6). Similar low correlation factors among TEs have been reported $30 \mathrm{~km}$ to the north by Mastrocicco et al. [37] The only correlation values higher than 0.5 are As and $\mathrm{Zn}$ with $\mathrm{Fe}$ (0.7 and 0.84, respectively), and Mn with Co (0.51). In the literature, the reduction of Fe and Mn hydroxides bringing As, Zn [31,109-111] and Co [39] into groundwater is well documented. Although $\mathrm{Ni}$ is also indicated as dependent on $\mathrm{Mn}$ concentration in solution, this correlation is not present in this aquifer. Correlation coefficients around 0.6 also exist between $\mathrm{Ag}, \mathrm{Cu}, \mathrm{La}, \mathrm{Mo}, \mathrm{Pb}$ and $\mathrm{V}$, indicating common source for these TEs. Although these correlation levels seem mainly imputable to $\mathrm{P} 10 \mathrm{~N}$, which reveals the highest concentrations of $\mathrm{Ag}, \mathrm{Cu}, \mathrm{La}, \mathrm{Mo}, \mathrm{Pb}$ and $\mathrm{V}$, they also correlate with fine sediments [112], measured as $\mathrm{SiO}_{2} / \mathrm{Al}_{2} \mathrm{O}_{3}<3$. It has to be noted that the P10N well is located on a canal bank within the Pialassa Baiona lagoon (see Figure 1). Many bio-monitoring studies performed in this lagoon revealed extremely high concentrations of heavy and trace metals, both in sediments and the water, attributed to the bordering industrial site [68,113]. So, high concentration of many TEs in this site could be attributed to industrial pollution, and not to natural processes.

Precipitation of generic sulfides and pyrite $\left(\mathrm{FeS}_{2}\right)$ is highly suitable in wells where both reduced $\mathrm{S}$ (from sulphate reduction process) and $\mathrm{Fe}^{2+}$ are concentrated in solution. During sulfide precipitation, other metals can be incorporated in pyrite, such as $\mathrm{Pb}, \mathrm{Zn}, \mathrm{Cd}, \mathrm{Co}, \mathrm{Ni}, \mathrm{Cu}, \mathrm{Mo}, \mathrm{Cr}$ and $\mathrm{As}$ [41]. At the opposite end, in environments like gravel pits and their surrounding area, where oxic water reaches the deepest aquifer layers due to excavation activities, pyrite oxidation occurs [32]. During pyrite oxidation, several TEs, like $\mathrm{Zn}, \mathrm{Ni}, \mathrm{Cu}, \mathrm{Mn}, \mathrm{Co}$ and As, are released into the solution [40,85,110]. Although not feasible during this present study, more investigations could be performed on sediment samples from the study area, as well as laboratory experiments to measure TEs released during pyrite oxidation under controlled conditions.

Close to the sea, where sulphate reduction does not occur, only Fe and Mn are utilized as electron acceptors for OM degradation, and carbonate concentration are elevated, solid phases of $\mathrm{Mn}$ and Fe, such as rhodochrosite and siderite, could precipitate, decreasing the concentration of $\mathrm{Mn}$ and Fe in the solution $[30,114]$.

\section{Summary and Conclusions}

The study area is wide $\left(400 \mathrm{~km}^{2}\right)$, includes many surface waters bodies (rivers, drainage channels, lagoons and gravel pit lakes), and the coastal aquifer is strongly salinized. The surface land use is complex: tourist-oriented coastal areas with the coexistence of natural areas (dunes, pine forests, wetlands, etc.), industrial areas and intensive agriculture activities.

With the aim of summarizing the main results for major and trace element concentrations, and relating the ongoing geochemical processes in coastal waters to current land use and management, six wells are selected as representative of existing environments. Specifically, P2S represents coastal dunes, P4S represents paleodunes, $\mathrm{P} 15 \mathrm{~N}$ and P11N represent fields, $\mathrm{P} 6 \mathrm{~S}$ represents nearby gravel pit activities and P14S represents the area of interaction between SW and GW. These wells (from P2S to P14S) are geographically oriented from sea to inland, and show a decreasing salinization from east (salinized) 
to west (freshwater). The median values are adopted as indicators for element abundance, and the summary is listed in Table 2. The complete statistics are available in Table S3.

Table 2. Summary of geochemical processes occurring in 5 selected environments in the study area. Color scale from red to green indicates from the highest to the lowest concentrations, respectively. TEs concentrations are in $\mu \mathrm{g} / \mathrm{L}$. Eh, $\mathrm{Cl}^{-}, \mathrm{HCO}_{3}{ }^{-}$are categorized using thresholds proposed by Stuyfzand 1989 [21]. $\mathrm{SO}_{4}{ }^{2-} / \mathrm{Cl}^{-}$equivalent ratio processes refer to Colombani et al. [12], $\mathrm{Cl}^{-} / \mathrm{Br}^{-}$molar ratio processes refer to Alcalà and Custodio [22].

\begin{tabular}{|c|c|c|c|c|c|}
\hline Environment & $\begin{array}{l}\text { Coastal Dunes } \\
\text { (e.g., P2S Well) }\end{array}$ & $\begin{array}{c}\text { Paleodunes } \\
\text { (e.g., P4S Well) }\end{array}$ & $\begin{array}{l}\text { Inland } \\
\text { Agricultural } \\
\text { Fields (e.g., } \\
\text { P11N and } \\
\text { P15N Wells) }\end{array}$ & $\begin{array}{l}\text { Gravel Pit (e.g., } \\
\text { P6S Well) }\end{array}$ & $\begin{array}{c}\text { Recent } \\
\text { Agricultural } \\
\text { Fields with } \\
\text { Ongoing } \\
\text { Infiltration } \\
\text { (e.g., P14S } \\
\text { Well) }\end{array}$ \\
\hline Eh & $\begin{array}{c}\text { Anoxic }(-120 \\
\mathrm{mV})\end{array}$ & $\begin{array}{c}\text { Anoxic }(-150 \\
\mathrm{mV})\end{array}$ & $\begin{array}{l}\text { Extreme anoxic } \\
\qquad(-200 \mathrm{mV})\end{array}$ & $\begin{array}{c}\text { Oxic and } \\
\text { weakly anoxic } \\
(-80 \mathrm{mv})\end{array}$ & $\begin{array}{c}\text { Oxic and } \\
\text { slightly anoxic } \\
(-40 \mathrm{mV})\end{array}$ \\
\hline $\mathrm{Cl}^{-}$ & Saline & Saline & Brackish saline & Brackish saline & Fresh brackish \\
\hline $\mathrm{HCO}_{3}{ }^{-}$ & $\begin{array}{l}\text { Moderately } \\
\text { high }\end{array}$ & Very high & Very high & High & $\begin{array}{c}\text { Moderately } \\
\text { high }\end{array}$ \\
\hline $\mathrm{SO}_{4}{ }^{2-} / \mathrm{Cl}^{-} \mathrm{eq}$ & Seawater & $\begin{array}{l}\text { Moderate } \\
\mathrm{SO}_{4}{ }^{2-} \\
\text { reduction }\end{array}$ & $\begin{array}{l}\text { Strong } \mathrm{SO}_{4}^{2-} \\
\text { reduction }\end{array}$ & $\begin{array}{l}\text { Mix Sea- and } \\
\text { freshwater }\end{array}$ & Freshwater \\
\hline $\mathrm{Cl}^{-} / \mathrm{Br}^{-}$molar & $\begin{array}{l}\text { Seawater } \\
\text { intrusion }\end{array}$ & Excess of $\mathrm{Br}^{-}$ & Excess of $\mathrm{Br}^{-}$ & $\begin{array}{l}\text { Seawater } \\
\text { intrusion }\end{array}$ & Freshwater \\
\hline Well & P2S & P4S & P11N e P15N & P6S & P14S \\
\hline Statistic & Median & Median & Median & Median & Median \\
\hline $\mathrm{Mn}$ & 2284 & 174 & 482 & 779 & 102 \\
\hline $\mathrm{Fe}$ & 11475 & 9100 & 2700 & 1800 & 36 \\
\hline $\mathrm{Ba}$ & 166 & 497 & 779 & 208 & 85 \\
\hline $\mathrm{Si}$ & 4600 & 7725 & 6250 & 8060 & 2018 \\
\hline $\mathrm{Ag}$ & 11.0 & $<0.05$ & 3.1 & $<0.05$ & $<0.05$ \\
\hline As & 45.0 & 37.5 & 27.5 & 15.0 & 8.7 \\
\hline Co & 1.5 & $<0.02$ & 0.5 & 3.6 & 0.4 \\
\hline $\mathrm{Cr}$ & 12.5 & $<0.5$ & $<0.5$ & 7.0 & 5.0 \\
\hline $\mathrm{Cu}$ & 12.5 & 7.5 & 17.5 & 16.0 & 4.2 \\
\hline $\mathrm{La}$ & 0.3 & $<0.01$ & 0.1 & 0.5 & $<0.01$ \\
\hline Mo & 5.0 & 5.0 & 5.0 & 3.0 & 3.4 \\
\hline $\mathrm{Ni}$ & $<0.2$ & $<0.2$ & 8.8 & 41.0 & 4.7 \\
\hline $\mathrm{Pb}$ & $<0.1$ & $<0.1$ & 5.0 & 1.5 & 0.6 \\
\hline $\mathrm{Sb}$ & $<0.05$ & $<0.05$ & $<0.05$ & $<0.05$ & 0.3 \\
\hline $\mathrm{U}$ & 0.75 & $<0.02$ & $<0.02$ & 16.1 & 1.9 \\
\hline $\mathrm{V}$ & 40.0 & 30.0 & 26.3 & 15.0 & 2.5 \\
\hline $\mathrm{Zn}$ & 400 & 75 & 96 & 95 & 35 \\
\hline B & 3400 & 3675 & 2925 & 2240 & 375 \\
\hline $\mathrm{Li}$ & 113 & 55 & 35 & 97 & 13 \\
\hline $\mathrm{Rb}$ & 37 & 36 & 25 & 26 & 4 \\
\hline $\mathrm{Sr}$ & 6643 & 6228 & 4557 & 5892 & 356 \\
\hline
\end{tabular}

Concentration differences among the different environments are significant; at least one order of magnitude exists between minimum and maximum values between the wells. In the case of Fe, almost three orders of magnitude exist between freshwater environment and paleodunes.

Coastal dune environments have been recently (since the last century) reclaimed by mechanical drainage [52], and nowadays are included in a protected natural area. These environments are widely 
salinized, and there are anoxic conditions and no sulphate reductions $\left(\mathrm{SO}_{4}{ }^{2-} / \mathrm{Cl}^{-}\right.$equivalent ratio $=0.1$ ), while high levels of $\mathrm{Fe}$ and $\mathrm{Mn}$ hydroxides reduction ( 2.3 and $11.5 \mathrm{mg} / \mathrm{L}$, respectively) is ongoing. Barium and Si concentrations are low, indicating weak water-sediment interaction and short water residence time. Boron, $\mathrm{Li}, \mathrm{Rb}$ and $\mathrm{Sr}$ concentrations are elevated and proportionate to salinity (conservative behavior). Among the other TEs, Ag, As, $\mathrm{Cr}, \mathrm{Zn}$ and $\mathrm{V}$ reach the highest concentrations, while $\mathrm{Ni}$ and $\mathrm{Pb}$ are absent. From the management point of view, the strong drainage rate affecting the area removes the small freshwater lenses present at the aquifer top, promoting the seepage of reduced water enriched in $\mathrm{Fe}, \mathrm{Mn}$, As and $\mathrm{Zn}$.

The paleodunes and old field environments are located more than $4 \mathrm{~km}$ from the shoreline (refer to Figure 1); their deposition started with the last transgressive phase and highstand period (10-6 thousand years $\mathrm{BP}$ ), characterized by the formation of several wetlands, with associated $\mathrm{OM}$ accumulation and abundance. The Eh values, $\mathrm{SO}_{4}{ }^{2-} / \mathrm{Cl}^{-}$equivalent ratio and $\mathrm{Ba}$ and $\mathrm{Si}$ concentrations suggest significant $\mathrm{OM}$ degradation with sulphate as the secondary oxidant. Manganese concentration is relatively low for the measured anoxic conditions, and this indicates possible rhodochrosite precipitation. Iron is still high in paleodunes $(9 \mathrm{mg} / \mathrm{L})$, while being poor $(2.7 \mathrm{mg} / \mathrm{L})$ in fields where pyrite precipitation processes occur. Silver, As, $\mathrm{Co}, \mathrm{Cr}, \mathrm{V}$ and $\mathrm{Zn}$ decrease their concentrations in GW, probably through sulfide precipitation [41]. However, the strongest reductive conditions permit the presence of $\mathrm{Cu}, \mathrm{Ni}$ and $\mathrm{Pb}$ in solution, especially in the field environment. The TEs with conservative behavior remain proportional to salinity. Even if paleodunes are potential recharge sites for the coastal aquifer, the infiltration is almost absent, and fresh and oxygenated water forms thin lenses, which are rapidly consumed by evapotranspiration from pine forests [16,17,52]. Inland fields are settled on silty clay continental sediments, which make the aquifer semi-confined or confined; here, the infiltration is diminished, and GW stagnation is favored, fostering sediment weathering.

The gravel pit environment is characterized by oxic conditions in pit lakes, and oscillation among oxic and anoxic conditions in surrounding GW. It has brackish saline GW, with no evidence of $\mathrm{OM}$ degradation, as verified by a high $\mathrm{SO}_{4}{ }^{2-} / \mathrm{Cl}^{-}$equivalent ratio. In this environment, pyrite dissolution occurs, leading to excesses of sulphate in the solution (maximum $\mathrm{SO}_{4}{ }^{2-} / \mathrm{Cl}^{-}$equivalent ratio $=6.4$, refer to Table S3). Furthermore, the Ni and Co abundance here are related to pyrite oxidation. Li abundance is evidence of ongoing freshening phenomenon [24]. The other TEs with conservative behavior are aligned with salinity. The excavation activities, verified by the highest $\mathrm{Si}$ concentration, expose the aquifer to atmosphere, increasing the water oxygenation and direct evaporation, fostering the deep seepage of saline GW. Both these phenomena generated a saline water environment where oxidation reactions occur; $\mathrm{Co}, \mathrm{La}, \mathrm{Ni}$ and $\mathrm{U}$ remain in solution, while Fe- and Mn- oxides adsorb heavy metals, like As, and precipitate.

Recent agricultural fields, where infiltration from drainage or rivers occurs, are characterized by oxic conditions in the uppermost part, and slightly anoxic trend in the bottom part. The oxygenated infiltration water does not allow $\mathrm{Mn}$ and Fe reduction. Moreover, the extremely low Ba and Si concentrations indicate low residence time and no water-sediment interaction. Obviously, conservative TEs have a low concentration, given the elevated contribution of freshwater to the mixing. Only $\mathrm{Ni}$, $\mathrm{Pb}, \mathrm{Sb}$ and $\mathrm{U}$ have concentrations aligned with, or even higher than, those in the other environments. In particular, $\mathrm{Sb}$ is supplied by the infiltration of irrigation water, while $\mathrm{U}$ by fertilizers.

The analysis of major elements and TEs in 104 SW and GW samples allows us to characterize the most relevant geochemical processes ongoing in the area, with our attention on GW. Results permit us to identify, describe, and correlate ongoing geochemical processes with current water management.

Water samples of rivers do not present any geochemical indication different from local background water. Drainage channels collect the uppermost water of the aquifer and show weak enrichments in seawater elements. Lagoon waters are the most enriched in many TEs, which come from the bordering industrial areas. Groundwater is almost completely saline, and only a few locations show interactions with surface fresh water. In locations with active infiltration and aquifer recharge, or those in the vicinity of gravel pit environments, oxidant conditions exist, and the precipitation of $\mathrm{Mn}$ - and Fe- 
hydroxides and oxides and pyrite oxidation occur. However, most GW samples show strongly anoxic conditions, and OM degradation is widely proven. Without oxygen, secondary oxidant compounds are involved, following the entire sequential reduction chain: $\mathrm{Mn}^{4+}, \mathrm{Fe}^{3+}, \mathrm{SO}_{4}{ }^{2-}$ and fermentation. In the recent deposition near the coast, elevated concentrations of $\mathrm{Mn}$ and Fe in solution, and no sulphate reduction, indicates moderate $\mathrm{OM}$ degradation. In most inner locations, the contemporary abundance of $\mathrm{Mn}, \mathrm{Fe}, \mathrm{H}_{2} \mathrm{~S}$ and $\mathrm{HCO}_{3}{ }^{-}$favor the precipitation of rhodochrosite, pyrite and siderite, with a decrease in solution of TEs like As, Ag, Co, Cr, V and $\mathrm{Zn}$. On the contrary, high rates of OM degradation increase the concentrations of $\mathrm{Cu}, \mathrm{Ni}$ and $\mathrm{Pb}$, which are released in the solution. The presented spatial distribution of sulphate reduction processes in the aquifer, along with stratigraphic reconstruction of the area, suggests that sulphate depletion could be used as a proxy for seawater intrusion in coastal aquifers where OM is present. Obviously, external or anthropic sulphate sources have to be excluded. Fe and Mn reduction is not related to seawater, but to sediment composition, and only identify anoxic condition in the aquifer.

The use of chemical and animal-made fertilizers seems to be source of B and $U$ in the solution in the agricultural areas. In some locations, agriculture is responsible for the excess of irrigation and freshwater storage, which locally improves GW quality. Where the aquifer is phreatic, the interaction between surface (rivers or drainage channels) and groundwater promotes freshening processes and TEs depletion. Since the 1970s, when groundwater withdrawal was forbidden in order to limit subsidence, drainage has been the most relevant human activity affecting and controlling groundwater quality and availability. The drainage lowers the water table and limits the natural recharge, favoring the occurrence of anoxic conditions in the aquifer. In light of the forecasting scenarios of sea level rise and decreases in precipitation, and in order to mitigate soil and water salinization, innovative water management practices, such as Manage Aquifer Recharge (MAR) techniques, or specifically Subsurface Water Technologies (SWT) [115], should be identified and tested in the area.

Supplementary Materials: The following are available online at http://www.mdpi.com/2073-4441/12/6/1720/s1, Figure S1: Matrix of correlation coefficients for major elements with salinity, grouped by environments as by Mollema et al. [54], Figure S2: Binary plot of $\mathrm{SO}_{4}{ }^{2-}$ versus $\mathrm{Cl}^{-}$of all water samples. The symbol size is proportional to $\mathrm{HCO}^{3-}$ concentration as indicated in legend on the left-hand side, Figure S3: Zoom of Figure 6 showing the water samples indicating both low $\mathrm{Cl}^{-} / \mathrm{Br}^{-}$molar ratio and organic matter degradation, Figure S4: Correlation coefficient matrix of $\mathrm{Cl}^{-}, \mathrm{B}, \mathrm{Li}, \mathrm{Rb}$, and $\mathrm{Sr}$ concentrations for all $\mathrm{GW}$ samples keeping rivers and sea as end members, Figure S5: Scatterplot of Fe vs. Mn for groundwater samples. Red dotted line indicates palaeodunes samples with $\mathrm{Mn}$ enrichments and contemporary low Fe concentration. At the opposite, green dotted line indicates samples from paleodunes and field environment with higher Fe concentration, Figure S6: Correlation coefficients matrix for TEs deriving by water-sediment interaction for all groundwater samples, Table S1: Database of the samples with specified name, coordinates, and sampling depths, Table S2: Descriptive statistics of major elements and ratios of all samples. "d.l." means detection limit, Table S3: Summary statistics for the six wells (P2S, P4S, P11N, P15N, P6S, P14S), which are selected to represent the main geochemical processing occurring in the study area.

Author Contributions: Conceptualization, N.G., B.M.S.G. and E.D.; Data curation, N.G.; Formal analysis, N.G.; Investigation, N.G., B.M.S.G., P.M., M.L. and D.C.; Project administration, G.G.; Supervision, M.A. and E.D.; Visualization, N.G., B.M.S.G.; Writing—original draft, N.G., B.M.S.G. and E.D.; Writing—review \& editing, N.G., B.M.S.G. and E.D. All authors have read and agreed to the published version of the manuscript.

Funding: This research was funded by Coastal Saltwater Intrusion (CSI) Project funded by Eni Spa.

Acknowledgments: This study was performed within the Coastal Saltwater Intrusion (CSI) Project funded by Eni Spa. The authors would like to thank the IGRG Lab people (Integrated Geosciences Research Group) of the University of Bologna, Valentina Marconi, Murugan Ramasamy, Sathish Sadhasivam, and Monica Cibien for their help in the field activities. We thank the private landowners who hosted monitored wells, and the Carabinieri for Biodiversity Punta Marina Office, who allowed the access to the protected natural areas. Moreover, we thank the editors and reviewers for the suggestions and help in improving the manuscript.

Conflicts of Interest: The authors declare no conflict of interest. 


\section{References}

1. Kummu, M.; De Moel, H.; Salvucci, G.; Viviroli, D.; Ward, P.J.; Varis, O. Over the hills and further away from coast: Global geospatial patterns of human and environment over the 20th-21st centuries. Environ. Res. Lett. 2016, 11, 34010. [CrossRef]

2. Jiao, J.; Post, V. Coastal Hydrogeology; Cambridge University Press: Cambridge, UK, 2019.

3. Flörke, M.; Bärlund, I.; Van Vliet, M.T.H.; Bouwman, A.F.; Wada, Y. Analysing trade-offs between SDGs related to water quality using salinity as a marker. Curr. Opin. Environ. Sustain. 2019, 36, 96-104. [CrossRef]

4. Caschetto, M.; Colombani, N.; Mastrocicco, M.; Petitta, M.; Aravena, R. Nitrogen and sulphur cycling in the saline coastal aquifer of Ferrara, Italy. A multi-isotope approach. Appl. Geochem. 2017, 76, 88-98. [CrossRef]

5. Giambastiani, B.M.S.; Colombani, N.; Greggio, N.; Antonellini, M.; Mastrocicco, M. Coastal aquifer response to extreme storm events in Emilia-Romagna, Italy. Hydrol. Process. 2017, 31, 1613-1621. [CrossRef]

6. Cozzolino, D.; Greggio, N.; Antonellini, M.; Giambastiani, B.M.S.; Davide, C.; Nicolas, G.; Marco, A. Natural and anthropogenic factors affecting freshwater lenses in coastal dunes of the Adriatic coast. J. Hydrol. 2017, 551, 804-818. [CrossRef]

7. Michael, H.A.; Mulligan, A.E.; Harvey, C.F. Seasonal oscillations in water exchange between aquifers and the coastal ocean. Nature 2005, 436, 1145-1148. [CrossRef]

8. Duncan, T.; Shaw, T.J. The Mobility of Rare Earth Elements and Redox Sensitive Elements in the Groundwater/Seawater Mixing Zone of a Shallow Coastal Aquifer. Aquat. Geochem. 2003, 9, 233-255. [CrossRef]

9. Custodio, E. Coastal aquifers of Europe: An overview. Hydrogeol. J. 2009, 18, 269-280. [CrossRef]

10. Werner, A.; Bakker, M.; Post, V.E.A.; Vandenbohede, A.; Lu, C.; Ataie-Ashtiani, B.; Simmons, C.T.; Barry, D. Seawater intrusion processes, investigation and management: Recent advances and future challenges. Adv. Water Resour. 2013, 51, 3-26. [CrossRef]

11. Essink, G.O.; Van Baaren, E.S.; De Louw, P.G.B. Effects of climate change on coastal groundwater systems: A modeling study in the Netherlands. Water Resour. Res. 2010, 46, 1-16. [CrossRef]

12. Colombani, N.; Mastrocicco, M. Geochemical evolution and salinization of a coastal aquifer via seepage through peaty lenses. Environ. Earth Sci. 2016, 75. [CrossRef]

13. Wassef, R.; Schüttrumpf, H. Impact of sea-level rise on groundwater salinity at the development area western delta, Egypt. Groundw. Sustain. Dev. 2016, 85-103. [CrossRef]

14. Colombani, N.; Osti, A.; Volta, G.; Mastrocicco, M. Impact of Climate Change on Salinization of Coastal Water Resources. Water Resour. Manag. 2016, 30, 2483-2496. [CrossRef]

15. Mollema, P.N.; Antonellini, M.; Dinelli, E.; Greggio, N.; Stuyfzand, P.J. The influence of flow-through saline gravel pit lakes on the hydrologic budget and hydrochemistry of a Mediterranean drainage basin. Limnol. Oceanogr. 2015, 60, 2009-2025. [CrossRef]

16. Mollema, P.N.; Antonellini, M.; Gabbianelli, G.; Galloni, E. Water budget management of a coastal pine forest in a Mediterranean catchment (Marina Romea, Ravenna, Italy). Environ. Earth Sci. 2012, 68, 1707-1721. [CrossRef]

17. Mollema, P.N.; Antonellini, M.; Gabbianelli, G.; Laghi, M.; Marconi, V.; Minchio, A. Climate and water budget change of a Mediterranean coastal watershed, Ravenna, Italy. Environ. Earth Sci. 2011, 65, 257-276. [CrossRef]

18. Greggio, N.; Mollema, P.N.; Antonellini, M.; Gabbianelli, G. Irrigation Management in Coastal Zones to Prevent Soil and Groundwater Salinization. In Resource Management for Sustainable Agriculture; IntechOpen: London, UK, 2012.

19. Vandenbohede, A.; Mollema, P.N.; Greggio, N.; Antonellini, M. Seasonal dynamic of a shallow freshwater lens due to irrigation in the coastal plain of Ravenna, Italy. Hydrogeol. J. 2014, 22, 893-909. [CrossRef]

20. Sprenger, C.; Hartog, N.; Hernández, M.; Vilanova, E.; Grützmacher, G.; Scheibler, F.; Hannappel, S. Inventory of managed aquifer recharge sites in Europe: Historical development, current situation and perspectives. Hydrogeol. J. 2017, 25, 1909-1922. [CrossRef]

21. Stuyfzand, P. A New Hydrochemical Classification of Water Types. In Regional Characterization of Water Quality; IAHS Publication: Oxford, UK, 1989; Volume 182, pp. 89-98.

22. Alcalá, F.J.; Custodio, E. Using the $\mathrm{Cl} / \mathrm{Br}$ ratio as a tracer to identify the origin of salinity in aquifers in Spain and Portugal. J. Hydrol. 2008, 359, 189-207. [CrossRef] 
23. Li, C.; Gao, X.; Liu, Y.; Wang, Y. Impact of anthropogenic activities on the enrichment of fluoride and salinity in groundwater in the Yuncheng Basin constrained by $\mathrm{Cl} / \mathrm{Br}$ ratio, $\delta 18 \mathrm{O}, \delta 2 \mathrm{H}, \delta 13 \mathrm{C}$ and $\delta 7 \mathrm{Li}$ isotopes. J. Hydrol. 2019, 579, 124211. [CrossRef]

24. Russak, A.; Sivan, O.; Yechieli, Y. Trace elements (Li, B, Mn and Ba) as sensitive indicators for salinization and freshening events in coastal aquifers. Chem. Geol. 2016, 441, 35-46. [CrossRef]

25. Appelo, C.; Postma, D. Introduction to Groundwater Geochemistry. In Geochemistry, Groundwater and Pollution; Informa UK Limited: London, UK, 2005; pp. 1-22.

26. Capaccioni, B.; Didero, M.; Paletta, C.; Didero, L. Saline intrusion and refreshening in a multilayer coastal aquifer in the Catania Plain (Sicily, Southern Italy): Dynamics of degradation processes according to the hydrochemical characteristics of groundwaters. J. Hydrol. 2005, 307, 1-16. [CrossRef]

27. Jakobsen, R.; Postma, D. Redox zoning, rates of sulfate reduction and interactions with Fe-reduction and methanogenesis in a shallow sandy aquifer, Rømø, Denmark. Geochim. Cosmochim. Acta 1999, 63, 137-151. [CrossRef]

28. Alewell, C.; Paul, S.; Lischeid, G.; Storck, F. Co-regulation of redox processes in freshwater wetlands as a function of organic matter availability? Sci. Total Environ. 2008, 404, 335-342. [CrossRef] [PubMed]

29. Yagües, V.G.; Botella, N.B.; Ruiz-Beviá, F. Gypsum precipitation/dissolution as an explanation of the decrease of sulphate concentration during seawater intrusion. J. Hydrol. 2000, 228, 48-55. [CrossRef]

30. Jensen, D.L.; Boddum, J.K.; Tjell, J.C.; Christensen, T.H. The solubility of rhodochrosite (MnCO3) and siderite (FeCO3) in anaerobic aquatic environments. Appl. Geochem. 2002, 17, 503-511. [CrossRef]

31. Anawar, H.M.; Akai, J.; Mihaljevič, M.; Sikder, A.M.; Ahmed, G.; Tareq, S.M.; Rahman, M.M. Arsenic Contamination in Groundwater of Bangladesh: Perspectives on Geochemical, Microbial and Anthropogenic Issues. Water 2011, 3, 1050-1076. [CrossRef]

32. Porowski, A.; Porowska, D.; Halas, S. Identification of Sulfate Sources and Biogeochemical Processes in an Aquifer Affected by Peatland: Insights from Monitoring the Isotopic Composition of Groundwater Sulfate in Kampinos National Park, Poland. Water 2019, 11, 1388. [CrossRef]

33. Biester, H.; Selimovic, D.; Hemmerich, S.; Petri, M. Halogens in pore water of peat bogs-The role of peat decomposition and dissolved organic matter. Biogeosciences 2006, 3, 53-64. [CrossRef]

34. Wen, X.; Lu, J.; Wu, J.; Lin, Y.; Luo, Y. Influence of coastal groundwater salinization on the distribution and risks of heavy metals. Sci. Total Environ. 2019, 652, 267-277. [CrossRef]

35. Mora, A.; Mahlknecht, J.; Ruiz, R.L.; Sanford, W.E.; Lesser, L.E. Dynamics of major and trace elements during seawater intrusion in a coastal sedimentary aquifer impacted by anthropogenic activities. J. Contam. Hydrol. 2020, 232, 103653. [CrossRef] [PubMed]

36. Giambastiani, B.M.S.; Colombani, N.; Mastrocicco, M. Detecting Small-Scale Variability of Trace Elements in a Shallow Aquifer. Water Air Soil Pollut. 2015, 226, 7. [CrossRef]

37. Mastrocicco, M.; Colombani, N.; Di Giuseppe, D.; Faccini, B.; Ferretti, G.; Coltorti, M. Abnormal trace element concentrations in a shallow aquifer belonging to saline reclaimed environments, Codigoro (Italy). Rend. Fis. Acc. Lincei 2015, 27, 95-104. [CrossRef]

38. Zhao, K.; Liu, X.; Xu, J.; Selim, H. Heavy metal contaminations in a soil-rice system: Identification of spatial dependence in relation to soil properties of paddy fields. J. Hazard. Mater. 2010, 181, 778-787. [CrossRef]

39. Kay, J.T.; Conklin, M.H.; Fuller, C.C.; O’Day, P.A. Processes of Nickel and Cobalt Uptake by a Manganese Oxide Forming Sediment in Pinal Creek, Globe Mining District, Arizona. Environ. Sci. Technol. 2001, 35, 4719-4725. [CrossRef] [PubMed]

40. Houben, G.J.; Sitnikova, M.A.; Post, V.E.A. Terrestrial sedimentary pyrites as a potential source of trace metal release to groundwater-A case study from the Emsland, Germany. Appl. Geochem. 2017, 76, 99-111. [CrossRef]

41. Morse, J.; Luther, G.W. Chemical influences on trace metal-sulfide interactions in anoxic sediments. Geochim. Cosmochim. Acta 1999, 63, 3373-3378. [CrossRef]

42. Dellwig, O.; E Böttcher, M.; Lipinski, M.; Brumsack, H. Trace metals in Holocene coastal peats and their relation to pyrite formation (NW Germany). Chem. Geol. 2002, 182, 423-442. [CrossRef]

43. Waseem, A.; Arshad, J.; Iqbal, F.; Sajjad, A.; Mehmood, Z.; Murtaza, G. Pollution Status of Pakistan: A Retrospective Review on Heavy Metal Contamination of Water, Soil, and Vegetables. BioMed Res. Int. 2014, 2014, 1-29. [CrossRef] 
44. Nagajyoti, P.C.; Lee, K.D.; Sreekanth, T.V.M. Heavy metals, occurrence and toxicity for plants: A review. Environ. Chem. Lett. 2010, 8, 199-216. [CrossRef]

45. Rasool, A.; Xiao, T.; Farooqi, A.; Shafeeque, M.; Masood, S.; Ali, S.; Fahad, S.; Nasim, W. Arsenic and heavy metal contaminations in the tube well water of Punjab, Pakistan and risk assessment: A case study. Ecol. Eng. 2016, 95, 90-100. [CrossRef]

46. Xu, M.; Sun, W.; Wang, R. Spatial Distribution and Ecological Risk Assessment of Potentially Harmful Trace Elements in Surface Sediments from Lake Dali, North China. Water 2019, 11, 2544. [CrossRef]

47. Abosede, O.A. Review on heavy metals contamination in the environment. Eur. J. Earth Environ. 2017, 4, 1-6.

48. Benini, L.; Antonellini, M.; Laghi, M.; Mollema, P.N. Assessment of Water Resources Availability and Groundwater Salinization in Future Climate and Land use Change Scenarios: A Case Study from a Coastal Drainage Basin in Italy. Water Resour. Manag. 2015, 30, 731-745. [CrossRef]

49. Greggio, N.; Giambastiani, B.M.; Campo, B.; Dinelli, E.; Amorosi, A. Sediment composition, provenance, and Holocene paleoenvironmental evolution of the Southern Po River coastal plain (Italy). Geol. J. 2017, 53, 914-928. [CrossRef]

50. Amorosi, A.; Colalongo, M.L.; Pasini, G.; Preti, D. Sedimentary response to Late Quaternary sea-level changes in the Romagna coastal plain (northern Italy). Sedimentology 1999, 46, 99-121. [CrossRef]

51. Giambastiani, B.M.S.; Colombani, N.; Mastrocicco, M.; Fidelibus, M.D. Characterization of the lowland coastal aquifer of Comacchio (Ferrara, Italy): Hydrology, hydrochemistry and evolution of the system. J. Hydrol. 2013, 501, 35-44. [CrossRef]

52. Antonellini, M.; Allen, D.M.; Mollema, P.N.; Capo, D.; Greggio, N. Groundwater freshening following coastal progradation and land reclamation of the Po Plain, Italy. Hydrogeol. J. 2015, 23, 1009-1026. [CrossRef]

53. Mollema, P.; Antonellini, M.; Dinelli, E.; Gabbianelli, G.; Greggio, N.; Stuyfzand, P. Hydrochemical and physical processes influencing salinization and freshening in Mediterranean low-lying coastal environments. Appl. Geochem. 2013, 34, 207-221. [CrossRef]

54. Sytnik, O.; Del Río, L.; Greggio, N.; Bonetti, J. Historical shoreline trend analysis and drivers of coastal change along the Ravenna coast, NE Adriatic. Environ. Earth Sci. 2018, 77, 779. [CrossRef]

55. Stefani, M.; Vincenzi, S. The interplay of eustasy, climate and human activity in the late Quaternary depositional evolution and sedimentary architecture of the Po Delta system. Mar. Geol. 2005, 222, $19-48$. [CrossRef]

56. Carbognin, L.; Tosi, L.; Teatini, P. Analysis of actual land subsidence in Venice and its hinterland (Italy). In Land Subsidence (Proceedings of the V International Symposium on Land Subsidence); Barends, F.B.J., Ed.; A.A. Balkema: Brookfield, VT, USA, 1995; pp. 129-137.

57. Antonellini, M.; Giambastiani, B.; Greggio, N.; Bonzi, L.; Calabrese, L.; Luciani, P.; Perini, L.; Severi, P. Processes governing natural land subsidence in the shallow coastal aquifer of the Ravenna coast, Italy. Catena 2019, 172, 76-86. [CrossRef]

58. Teatini, P.; Ferronato, M.; Gambolati, G.; Bertoni, W.; Gonella, M. A century of land subsidence in Ravenna, Italy. Environ. Earth Sci. 2005, 47, 831-846. [CrossRef]

59. Gambolati, G.; Teatini, P.; Tomasi, L.; Gonella, M. Coastline regression of the Romagna Region, Italy, due to natural and anthropogenic land subsidence and sea level rise. Water Resour. Res. 1999, 35, 163-184. [CrossRef]

60. Greggio, N.; Giambastiani, B.M.S.; Antonellini, M. Infiltration/Irrigation Trench for Sustainable Coastal Drainage Management: Emilia-Romagna (Italy). Environ. Eng. Manag. J. 2018, 17, 2379-2390. [CrossRef]

61. Antonellini, M.; Mollema, P.; Giambastiani, B.M.S.; Bishop, K.; Caruso, L.; Minchio, A.; Pellegrini, L.; Sabia, M.; Ulazzi, E.; Gabbianelli, G. Salt water intrusion in the coastal aquifer of the southern Po Plain, Italy. Hydrogeol. J. 2008, 16, 1541-1556. [CrossRef]

62. Fabbri, S.; Giambastiani, B.M.; Sistilli, F.; Scarelli, F.; Gabbianelli, G. Geomorphological analysis and classification of foredune ridges based on Terrestrial Laser Scanning (TLS) technology. Geomorphology 2017, 295, 436-451. [CrossRef]

63. Amorosi, A.; Colalongo, M.; Fiorini, F.; Fusco, F.; Pasini, G.; Vaiani, S.; Sarti, G. Palaeogeographic and palaeoclimatic evolution of the Po Plain from 150-ky core records. Glob. Planet. Chang. 2004, 40, 55-78. [CrossRef]

64. Giambastiani, B.M.S.; Macciocca, V.R.; Molducci, M.; Antonellini, M. Factors Affecting Water Drainage Long-Time Series in the Salinized Low-Lying Coastal Area of Ravenna (Italy). Water 2020, 12, 256. [CrossRef] 
65. Antonellini, M.; Mollema, P.N. Impact of groundwater salinity on vegetation species richness in the coastal pine forests and wetlands of Ravenna, Italy. Ecol. Eng. 2010, 36, 1201-1211. [CrossRef]

66. Lide, D.R. CRC Handbook of Chemistry and Physics, 77th ed.; CRC Press: Boca Raton, FL, USA, 1996.

67. Loader, N. Book Review: Chemical elements in the environment: Factsheets for the geochemist and environmental scientist. Holocene 1999, 9, 377-378. [CrossRef]

68. Franzellitti, S.; Buratti, S.; Donnini, F.; Fabbri, E. Exposure of mussels to a polluted environment: Insights into the stress syndrome development. Comp. Biochem. Physiol. Part C Toxicol. Pharmacol. 2010, 152, 24-33. [CrossRef] [PubMed]

69. Stuyfzand, P.J. Hydrochemistry and Hydrology of the Coastal Dune Area of the Western Netherlands. Ph.D. Thesis, Vrije Universiteit Amsterdam, Amsterdam, The Netherlands, 1993.

70. Giambastiani, B.M.S.; Greggio, N.; Nobili, G.; Dinelli, E.; Antonellini, M. Forest fire effects on groundwater in a coastal aquifer (Ravenna, Italy). Hydrol. Process. 2018, 32, 2377-2389. [CrossRef]

71. Greggio, N.; Giambastiani, B.M.S.; Balugani, E.; Amaini, C.; Antonellini, M. High-Resolution Electrical Resistivity Tomography (ERT) to Characterize the Spatial Extension of Freshwater Lenses in a Salinized Coastal Aquifer. Water 2018, 10, 1067. [CrossRef]

72. Barbarella, M.; De Giglio, M.; Panciroli, L.; Greggio, N. Satellite data analysis for identification of groundwater salinization effects on coastal forest for monitoring purposes. In Proceedings of the International Association of Hydrological Sciences, Guangzhou, China, 24-27 August 2014; pp. 325-330.

73. Italiana, R. Decreto Legislativo 3 aprile 2006, n. 152. Gazz. Uff. 2006, 1, 172.

74. Lancianese, V.; Dinelli, E. Different spatial methods in regional geochemical mapping at high density sampling: An application on stream sediment of Romagna Apennines, Northern Italy. J. Geochem. Explor. 2015, 154, 143-155. [CrossRef]

75. Lancianese, V.; Dinelli, E. Geochemical mapping based on geological units: A case study from the Marnoso-arenacea formation (Northern Apennines, Italy). Chem. Erde Geochem. 2016, 76, 49-62. [CrossRef]

76. Barker, A.P.; Newton, R.; Bottrell, S.H.; Tellam, J. Processes affecting groundwater chemistry in a zone of saline intrusion into an urban sandstone aquifer. Appl. Geochem. 1998, 13, 735-749. [CrossRef]

77. Andersen, M.S.; Nyvang, V.; Jakobsen, R.; Postma, D. Geochemical processes and solute transport at the seawater/freshwater interface of a sandy aquifer. Geochim. Cosmochim. Acta 2005, 69, 3979-3994. [CrossRef]

78. Jørgensen, B.B.; Postgate, J.R.; Miller, H.G.; Unsworth, M.H.; Rosenqvist, I.T.; Abrahamsen, G. Ecology of the bacteria of the sulphur cycle with special reference to anoxic-Oxic interface environments. Philos. Trans. R. Soc. Ser. B Boil. Sci. 1982, 298, 543-561. [CrossRef]

79. Leri, A.C.; Hakala, J.A.; Marcus, M.A.; Lanzirotti, T.; Reddy, C.M.; Myneni, S.C.B. Natural organobromine in marine sediments: New evidence of biogeochemical Br cycling. Glob. Biogeochem. Cycles 2010, $24,4$. [CrossRef]

80. Seki, A.; Tada, R.; Kurokawa, S.; Murayama, M. High-resolution Quaternary record of marine organic carbon content in the hemipelagic sediments of the Japan Sea from bromine counts measured by XRF core scanner. Prog. Earth Planet. Sci. 2019, 6, 1. [CrossRef]

81. Müller, G.; Nkusi, G.; Schöler, H.F. Natural Organohalogens in Sediments. J. für Praktische Chem. 1996, 338, 23-29. [CrossRef]

82. Mahn, C.; Gieskes, J. Halide systematics in comparison with nutrient distributions in sites 1033B and 1034B, Saanich Inlet: ODP Leg 169S. Mar. Geol. 2001, 174, 323-339. [CrossRef]

83. Martin, J.B.; Gieskes, J.M.; Torres, M.; Kastner, M. Bromine and iodine in Peru margin sediments and pore fluids: Implications for fluid origins. Geochim. Cosmochim. Acta 1993, 57, 4377-4389. [CrossRef]

84. Gerritse, R.G.; George, R.J. The role of soil organic matter in the geochemical cycling of chloride and bromide. J. Hydrol. 1988, 101, 83-95. [CrossRef]

85. Larsen, F.; Postma, D. Nickel Mobilization in a Groundwater Well Field: Release by Pyrite Oxidation and Desorption from Manganese Oxides. Environ. Sci. Technol. 1997, 31, 2589-2595. [CrossRef]

86. Bortolini, L.; Maucieri, C.; Borin, M. A Tool for the Evaluation of Irrigation Water Quality in the Arid and Semi-Arid Regions. Agronomy 2018, 8, 23. [CrossRef]

87. Ayers, R.S.; Dennis, W.W. Water Quality for Agriculture; Food and Agriculture Organization of the United Nations: Rome, Italy, 1985.

88. Liesch, T.; Hinrichsen, S.; Goldscheider, N. Uranium in groundwater-Fertilizers versus geogenic sources. Sci. Total Environ. 2015, 536, 981-995. [CrossRef] [PubMed] 
89. Australia Government Initiative. Guidelines for Fresh and Marine Water Quality. Available online: https://www.waterquality.gov.au/anz-guidelines/guideline-values/default/water-quality-toxicants/ toxicants/lanthanum-2000 (accessed on 24 April 2020).

90. Virginia Department of Health Lithium. 1997. Available online: https://water-research.net/index.php/lithium (accessed on 26 April 2020).

91. Chappell, W.R.; Meglen, R.R. Human Health Effects of Molybdenum in Drinking Water; Environmental Protection Agency, Office of Research and Development, Health Effects Research Laboratory: Washington, DC, USA, 1979; Volume 1. Available online: https://cfpub.epa.gov/si/si_public_record_Report.cfm?Lab=ORD\& dirEntryId=38852 (accessed on 26 April 2020).

92. Canadian Federal-Provincial-Territorial Committee on Drinking. Water Strontium in Drinking Water-Guideline Technical Document for Public Consultation. 2018. Available online: https://www. canada.ca/en/health-canada/programs/consultation-strontium-drinking-water/document.html\#1 (accessed on 27 April 2020).

93. Stuyfzand, P.J. Patterns in groundwater chemistry resulting from groundwater flow. Hydrogeol. J. 1999, 7, 15-27. [CrossRef]

94. Lyons, W.B.; Gardner, C.B.; Welch, S.A.; Israel, S. Uranium in Ohio, USA Surface Waters: Implications for a Fertilizer Source in Waters Draining Agricultural lands. Sci. Rep. 2020, 10, 1-6. [CrossRef] [PubMed]

95. Yamaguchi, N.; Kawasaki, A.; Iiyama, I. Distribution of uranium in soil components of agricultural fields after long-term application of phosphate fertilizers. Sci. Total Environ. 2009, 407, 1383-1390. [CrossRef] [PubMed]

96. Polack, R.; Chen, Y.-W.; Belzile, N. Behaviour of $\mathrm{Sb}(\mathrm{V})$ in the presence of dissolved sulfide under controlled anoxic aqueous conditions. Chem. Geol. 2009, 262, 179-185. [CrossRef]

97. Tang, J.; Johannesson, K.H. Speciation of rare earth elements in natural terrestrial waters: Assessing the role of dissolved organic matter from the modeling approach. Geochim. Cosmochim. Acta 2003, 67, 2321-2339. [CrossRef]

98. Cidu, R.; Antisari, L.V.; Biddau, R.; Buscaroli, A.; Carbone, S.; Da Pelo, S.; Dinelli, E.; Vianello, G.; Zannoni, D. Dynamics of rare earth elements in water-soil systems: The case study of the Pineta San Vitale (Ravenna, Italy). Geoderma 2013, 193, 52-67. [CrossRef]

99. Forcada, E.G.; Morell, I. Contributions of boron isotopes to understanding the hydrogeochemistry of the coastal detritic aquifer of Castellón Plain, Spain. Hydrogeol. J. 2008, 16, 547-557. [CrossRef]

100. Ravenscroft, P.; McArthur, J.M. Mechanism of regional enrichment of groundwater by boron: The examples of Bangladesh and Michigan, USA. Appl. Geochem. 2004, 19, 1413-1430. [CrossRef]

101. Jones, B.F.; Vengosh, A.; Rosenthal, E.; Yechieli, Y. Geochemical investigations. In Seawater Intrusion in Coastal Aquifers: Concepts, Methods and Practices; Springer: Berlin/Heidelberg, Germany, 1999; pp. 51-71.

102. Vengosh, A. Salinization and Saline Environments. In Treatise on Geochemistry; Elsevier BV: Amsterdam, The Netherlands, 2003; pp. 1-35.

103. Colombani, N.; Mastrocicco, M.; Dinelli, E. Trace elements mobility in a saline coastal aquifer of the Po river lowland (Italy). J. Geochem. Explor. 2015, 159, 317-328. [CrossRef]

104. Stuyfzand, P.J. Behaviour of major and trace constituents in fresh and salt intrusion waters, in the western Netherlands. In Proceedings of the 12th Salt Water Intrusion Meeting, Barcelona, Spain, 1-6 November 1992; pp. 143-160.

105. Negrel, P.; Millot, R.; Brenot, A.; Bertin, C. Lithium isotopes as tracers of groundwater circulation in a peat land. Chem. Geol. 2010, 276, 119-127. [CrossRef]

106. Gascho, G.J. Chapter 12 Silicon sources for agriculture. In Silicon in Agriculture; Elsevier BV: Amsterdam, The Netherlands, 2001; Volume 8, pp. 197-207.

107. Marandi, A.; Karro, E.; Puura, E. Barium anomaly in the Cambrian-Vendian aquifer system in North Estonia. Environ. Earth Sci. 2004, 47, 132-139. [CrossRef]

108. Lovley, D.R. Dissimilatory Fe(III) and Mn(IV) reduction. Microbiol. Rev. 1991, 55, 259-287. [CrossRef] [PubMed]

109. Pedersen, H.D.; Postma, D.; Jakobsen, R. Release of arsenic associated with the reduction and transformation of iron oxides. Geochim. Cosmochim. Acta 2006, 70, 4116-4129. [CrossRef]

110. McArthur, J.M.; Ravenscroft, P.; Safiulla, S.; Thirlwall, M.F. Arsenic in groundwater: Testing pollution mechanisms for sedimentary aquifers in Bangladesh. Water Resour. Res. 2001, 37, 109-117. [CrossRef] 
111. Zhang, Z.; Xiao, C.; Adeyeye, O.; Yang, W.; Liang, X. Source and Mobilization Mechanism of Iron, Manganese and Arsenic in Groundwater of Shuangliao City, Northeast China. Water 2020, 12, 534. [CrossRef]

112. Dinelli, E.; Tateo, F.; Summa, V. Geochemical and mineralogical proxies for grain size in mudstones and siltstones from the Pleistocene and Holocene of the Po River alluvial plain, Italy. Spec. Pap. Geol. Soc. Am. 2007, 420, 25-36. [CrossRef]

113. Donnini, F.; Dinelli, E.; Sangiorgi, F.; Fabbri, E. A biological and geochemical integrated approach to assess the environmental quality of a coastal lagoon (Ravenna, Italy). Environ. Int. 2007, 33, 919-928. [CrossRef]

114. Bojanowski, M.; Jaroszewicz, E.; Košir, A.; Łoziński, M.; Marynowski, L.; Wysocka, A.; Derkowski, A. Root-related rhodochrosite and concretionary siderite formation in oxygen-deficient conditions induced by a ground-water table rise. Sedimentology 2015, 63, 523-551. [CrossRef]

115. Zuurbier, K.G.; Raat, K.J.; Paalman, M.; Oosterhof, A.T.; Stuyfzand, P.J. How Subsurface Water Technologies (SWT) can Provide Robust, Effective, and Cost-Efficient Solutions for Freshwater Management in Coastal Zones. Water Resour. Manag. 2016, 31, 671-687. [CrossRef]

(C) 2020 by the authors. Licensee MDPI, Basel, Switzerland. This article is an open access article distributed under the terms and conditions of the Creative Commons Attribution (CC BY) license (http://creativecommons.org/licenses/by/4.0/). 